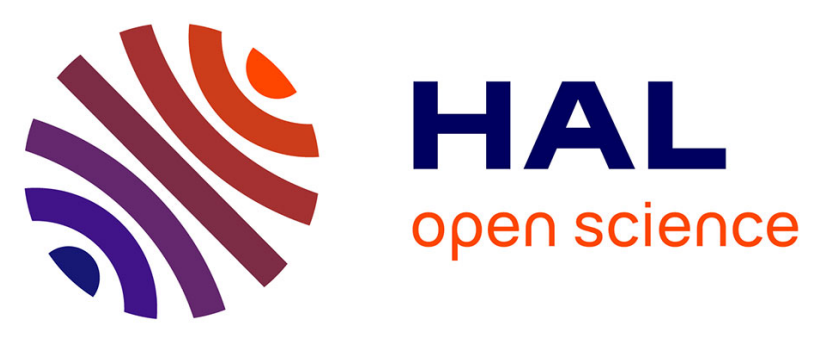

\title{
Caribbean plate boundaries control on the tectonic duality in the back-arc of the Lesser Antilles subduction zone during the Eocene
}

Nestor G. Cerpa, Riad Hassani, Diane Arcay, Serge Lallemand, Clément Garrocq, Mélody Philippon, Jean-Jacques Cornee, Philippe Münch, Fanny Garel, Boris Marcaillou, et al.

\section{To cite this version:}

Nestor G. Cerpa, Riad Hassani, Diane Arcay, Serge Lallemand, Clément Garrocq, et al.. Caribbean plate boundaries control on the tectonic duality in the back-arc of the Lesser Antilles subduction zone during the Eocene. Tectonics, 2021, 40 (11), pp.e2021TC006885. 10.1029/2021TC006885 . hal-03360128v2

\author{
HAL Id: hal-03360128 \\ https://hal.science/hal-03360128v2
}

Submitted on 25 Nov 2021

HAL is a multi-disciplinary open access archive for the deposit and dissemination of scientific research documents, whether they are published or not. The documents may come from teaching and research institutions in France or abroad, or from public or private research centers.
L'archive ouverte pluridisciplinaire HAL, est destinée au dépôt et à la diffusion de documents scientifiques de niveau recherche, publiés ou non, émanant des établissements d'enseignement et de recherche français ou étrangers, des laboratoires publics ou privés.

\section{(c)(1)}

Distributed under a Creative Commons Attribution| 4.0 International License 


\title{
Caribbean plate boundaries control on the tectonic duality in the back-arc of the Lesser Antilles subduction zone during the Eocene
}

\author{
N. G. Cerpa ${ }^{1,2, *}$, R. Hassani ${ }^{2}$, D. Arcay ${ }^{1}$, S. Lallemand ${ }^{1}$, C. Garrocq ${ }^{1}$, M. Philippon ${ }^{3}$, J.-J. Cornée ${ }^{3}$, \\ P. Münch ${ }^{1}$, F. Garel ${ }^{1}$, B. Marcaillou ${ }^{2}$, B. Mercier de Lépinay ${ }^{2}$, and J.-F. Lebrun ${ }^{3}$ \\ ${ }^{1}$ Geosciences Montpellier, University de Montpellier, CNRS, Université des Antilles, Place Eugène \\ Bataillon, 34095 Montpellier, France. \\ ${ }^{2}$ Geoazur, Université Côte d'Azur, CNRS, Observatoire de la Côte d'Azur, IRD, 250 Avenue Albert \\ Einstein, 06560 Valbonne, France. \\ ${ }^{3}$ Geosciences Montpellier, Université des Antilles, Université de Montpellier, CNRS, Campus Fouillole, \\ Pointe-à-Pitre, Guadeloupe (FWI), France.
}

*Corresponding author: Nestor G. Cerpa (nestor.cerpa@umontpellier.fr)

\begin{abstract}
The Eocene tectonic evolution of the easternmost Caribbean Plate (CP) boundary, i.e. the Lesser Antilles subduction zone (LASZ), is debated. Recents works shed light on a peculiar period of tectonic duality in the arc/back-arc regions. A compressional-to-transpressional regime occurred in the north, while rifting and seafloor spreading occurred in Grenada basin to the south. The mechanism for this strong spatial variation and its evolution through time has yet to be established. Here, using 3-D subduction mechanical models, we evaluate whether the change in the trench-curvature radius at the northeast corner of the CP could have modulated the duality. We assume asymmetrical CP boundaries at the north (from east to west: oblique subduction to strike-slip) and at the south (subduction-transform edge propagator-like behavior). Regardless of the imposed trench curvature, the southern half of our modeled CP undergoes a NW-to-Woriented extension due to the tendency of the southernmost part of the South-America oceanic slab to rollback. In contrast, the tectonic regime in the northeast corner of the $\mathrm{CP}$ depends on the trench-curvature radius. A low radius promotes transtension-to-transpression, with a NE-oriented compressive component of the principal stress. A high radius largely reduces the compressive component and promotes an extensional regime similar to that in the south. We thus propose that an initially low-curvature radius of the NE-LASZ triggered the tectonic N-S duality in the Eocene and led to an ephemeral period of transpression/compression at the north. However, an additional mechanism might have been required to locally enhance compression.
\end{abstract}




\section{Introduction}
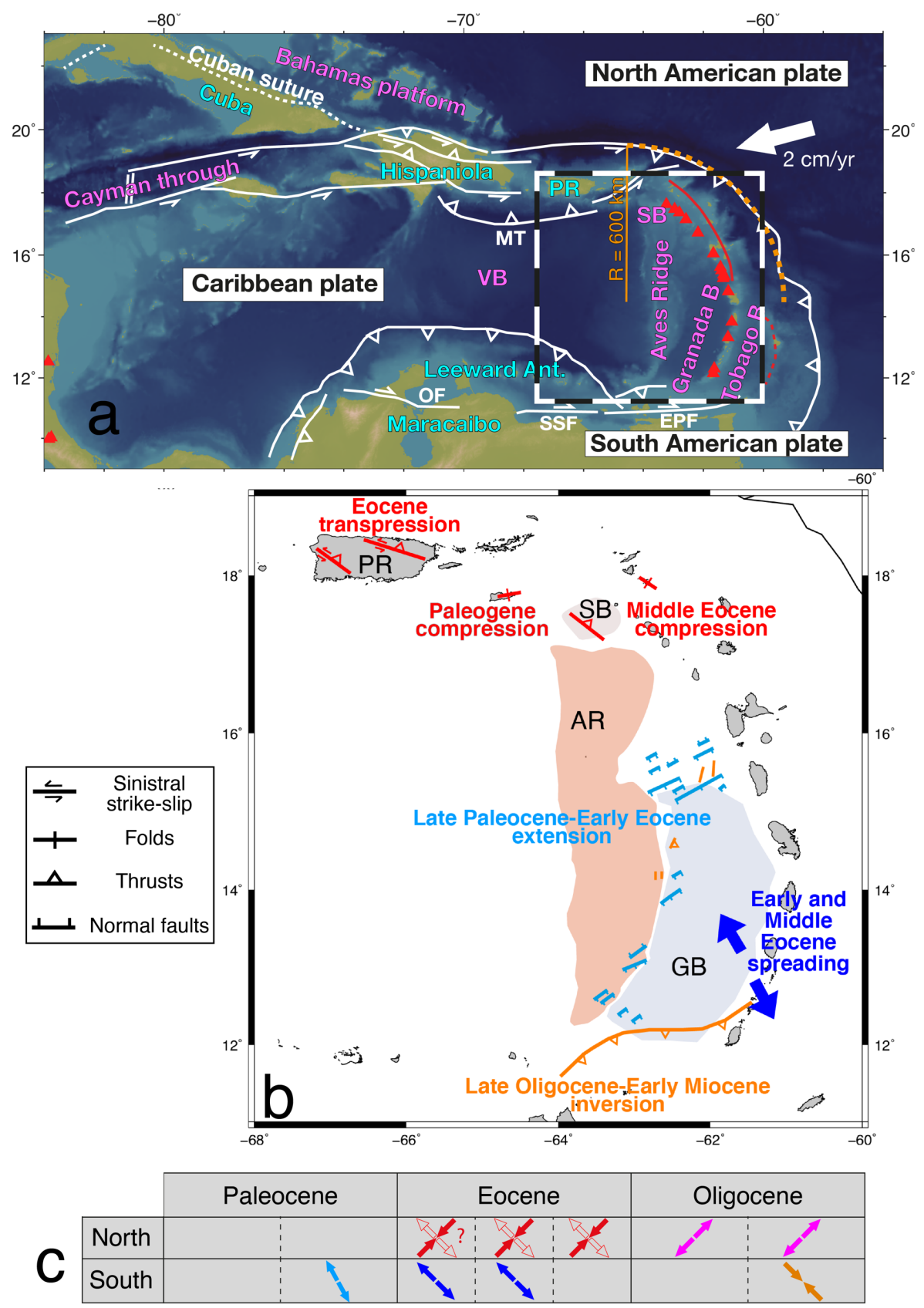

Figure 1 : a) Map of the Caribbean region with active plate boundaries and major faults with the region of interest at the east. The orange dashed line denotes the approximate radius of curvature of the present-day Lesser Antilles trench. b) Reported main faulting systems indicating the deformation modes at the surface of the Caribbean plate at various times during the Paleogene. MT: Muertos trough;VB: Venezuela Basin; SB: Saba Bank; AR: Aves Ridge; GB: Grenada basin. OF: Oca fault; PR: Puerto Rico; SSF: San Sebastian fault; EPF: El Pilar fault. c) Table illustrating the tectonic duality in the arc/back-arc region of the LASZ. The arrow colors correspond to that of the structures in panel b) with the exception of the Oligocene inversion (magenta) observed in the Saba bank and St. Barth (Philippon et al., 2020a) but not reported in the map. 
The Lesser Antilles Subduction Zone (hereafter LASZ), at the easternmost boundary of the narrow Caribbean plate is one of the most arcuate subduction zone at present-day (Fig. 1a). The subducting plate of the LASZ consists of both the North and South American plates, hereafter collectively referred to as the American plates, since their relative motion in the study area is negligeable. To the north, the convergence between the American and the Caribbean plates is highly oblique (ten Brink \& Lin, 2004; Legendre et al., 2018; Laurencin et al., 2019) and evolves to pure strike-slip motion in western Hispaniola and South Cuba (Calais et al., 2002; Mann et al., 2002; Rodriguez-Zurrunero et al., 2020), where a transform fault-system connects the plate boundary to the Cayman Trough (Leroy et al., 2000). At the south, the plate boundary is predominantly strike-slip and formed by a Subduction-Transform Edge Propagator (STEP) fault (Govers \& Wortel, 2005) in as much as the subducting plate tears as it subducts (VanDecard et al. 2003, Clark et al 2008; Padron et al. 2020). Both the north and the south strike-slip plate boundaries as well as the shape of the subduction trench have been mostly acquired during the Eocene (Pindell and Kennan, 2009; Escalona and Mann 2011; Philippon et al., 2020b).

Intriguingly, major tectonic events are thought to have occurred during the Eocene. Recent studies have revealed a period of shortening in the arc/back-arc of the Northern Lesser Antilles which may have been associated to a regional uplift in the middle to late Eocene (emersion of the GraNoLA land, (Philippon et al., 2020a)). In the island of Puerto Rico a transpressional tectonic regime has also been recorded in the Eocene (Lao-Davila et al., 2014). Though, while compressional/transpressional deformation occurred in the northern arc/back-area, the southern part underwent stretching and spreading in the early and middle Eocene, respectively (Bouysse et al., 1988; Garrocq et al., 2021). Thus, we postulate that these regional deformation patterns were induced by a compressional tectonic regime in the Northern Lesser Antilles and an extensional regime in the Southern Lesser Antilles. Hereafter, we refer to this peculiar regional stress field to as the Eocene-tectonic duality of the LASZ. This episode of latitudinal variation ended in the late Eocene and may have coincided with or preceded trench bending at the northern LASZ.

The present contribution aims to decipher whether the evolution of the trench curvature during the Eocene, along with a northern subduction-to-strike-slip boundary and a southern free subduction boundary (STEP fault), could have provoked a spatio-temporal strong variation in the state of stress from north to south at the easternmost Caribbean plate (Fig. 1b).

The three-dimensional shape of the subduction trench and the convergence obliquity was shown to impact the stress field at the surface of the overriding plate (Bonnardot et al., 2008b). These authors showed that symmetric sea-wards (subducting-plate-wards) concave and convex margins lead to trench-parallel tension and compression, respectively, in the forearc/arc area near the apex of the curvature. That is because the direction of non-hydrostatic forces at the subduction interface either diverge from or converge to that area of the forearc in concave and convex settings, respectively. Furthermore, shear stresses along the subduction interface induce shear parallel to the trench in the forearc region where the convergence is 
the most oblique, for instance at both sides of a symmetrical curved margin (Boutelier \& Oncken, 2010). Obliquity can further lead to strain partitioning and to localization of shear in pre-weakened areas such as the arc region (Chemenda et al., 2000). In nature, these 3-d effects may have affected regions of arcuate subduction trenches such as the Bolivian orocline (Boutelier \& Oncken, 2010) or the western Aleutians (Ryan and Scholl, 1989). In the Northern Lesser Antilles, Paleogene V-shaped basins in the forearc may

have resulted from the bending of the trench and from the development of a convex subduction setting which could have favored regional-scale block rotations (Laurencin et al., 2017; Boucard et al., 2021). The basins developed under the influence of a strong convergence obliquity along a highly curved trench which promoted trench-parallel forearc extension since at least the end of the Oligocene (e.g. Feuillet et al. 2002; Boucard et al., 2021). It is plausible that a temporal variation in trench curvature and subsequent convergence obliquity during the Eocene affected the spatio-temporal evolution of the stress field in the arc/back-arc region of the LASZ, but such an impact remains yet to be quantified.

Here, by using three-dimensional mechanical subduction models, we show that a low trench-curvature radius could have promoted a tectonic duality in the LASZ from early to mid- Eocene, favoring a transpressive event in the northern arc/back-arc area. An increasing curvature radius from the middle-tolate Eocene may have assisted a relief of compressive stresses in the same region. Below, we first describe the geodynamical setting of the LASZ during the Paleogene, focusing on Eocene times. Then, we describe the numerical approach that we undertake before presenting our modeling results and their implication for the regional tectonic evolution.

\section{Tectonic Setting}

The integrated story of the Caribbean plate and associated subduction zones has been described in various tectonic reconstructions (e.g., Meschede and Frisch, 1998; James 2009; Pindell and Kennan, 2009; Boschman et al., 2014). The onset of westward subduction at the north-eastern boundary of the Caribbean plate occurred in the Cretaceous, probably not later than 90 Ma (Pindell \& Kennan, 2009; Mann, 2007). Until the late Paleocene, the Caribbean plate hosted a volcanic arc which spanned the width of the plate, called the Great Arc of the Caribbean (GAC) (Burke et al., 1978). This former arc was associated with the SW-dipping subduction of a proto-Caribbean seafloor and was contemporaneous of a NE-SW relative convergence between the Caribbean plate and the Americas. From the end of the Paleocene to the early Eocene, the volcanic activity of the GAC ceased (Fig. 2a). At the easternmost part of the Caribbean plate, corresponding to the LASZ at present-day, the volcanic front migrated eastwards from the Aves ridge to the Lesser Antilles arc between the early and the middle Eocene (Fig. 2b). The relative convergence between the Caribbean and the American plates switched to E-W. This plate reorganization was accompanied by major tectonic events in Paleocene and Eocene times, which we highlight below. Our brief description follows a geographic path from North to South. 
From the Paleocene to the early Eocene, the northern segment of the GAC, presently corresponding to western and central Cuba, collided with the buoyant Bahamas platform and led to the formation of an orogenic belt (Iturralde-Vinent et al., 1994; Garcia-Casco et al., 2008; Cruz-Orosa et al., 2012) (Fig. 2a). Thrusting of the Cuban terranes onto the Bahamas platform was achieved by early middle-Eocene and led to the formation of the Cuban suture zone (Bralower and Iturralde-Vinent, 1997; Stanek et al., 2009). During the frontal arc-Bahamas collision, the direction of shortening in Central Cuba was reported to pass from a SSW-NNE orientation before the early Eocene, to a SW-NE orientation in middle-Eocene and to WSW-ENE after Mid-Eocene (Cruz-Orosa et al., 2012), which may illustrate a possible tectonic reorganization during the early Eocene.
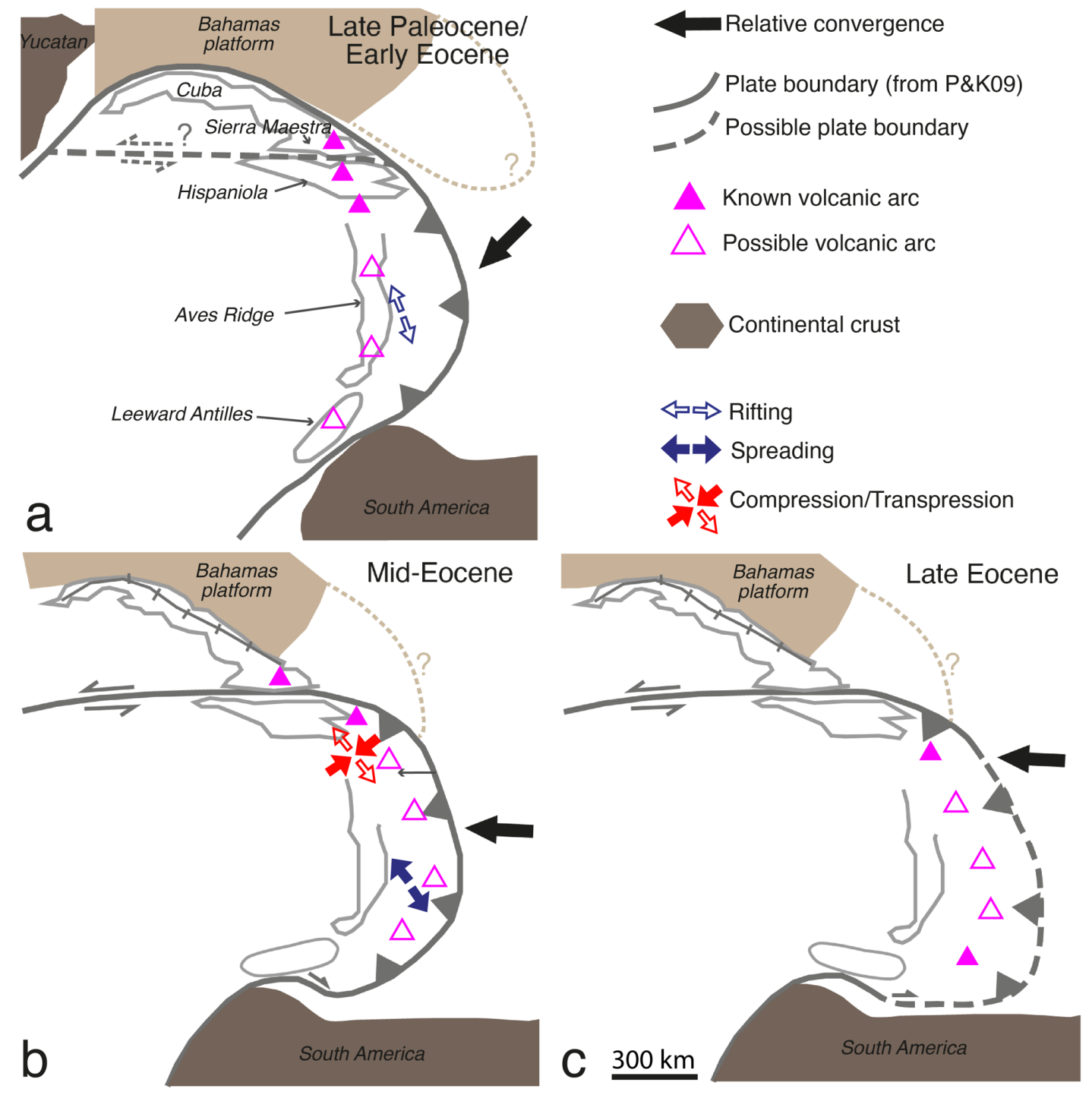

Figure 2 : Illustrative cartoon of the evolution of the tectonic setting of the Caribbean. The stages at the late Paleocene and Mid-Eocene are modified from Pindell \& Kennan, [2009]. We have also sketched a possible extension of the Bahamas platform following e.g. Lao-Davila et al., 2014. The stage at the late Eocene is modified from the Mid-Eocene reconstruction in Pindell \& Kennan 2009 by adding an assumption on the southern trench evolution following spreading in the Grenada basin. 
The collision ultimately caused the jump of the Caribbean-North America plate boundary towards an EW transform system south of Cuba (Fig. 2a). South of the Sierra Maestra, the strike-slip motion was accommodated by the opening of the Cayman Through from 50-49 Ma (Rosencrantz et al., 1988; Leroy et al., 2000). Prior to the spreading, a period of rifting (pull apart basin) may have started as early as the late Paleocene (Pubellier et al., 2000). Rosencrantz (1990) proposed that the E-W strike-slip motion between the plates was coeval with the thrusting of Cuba onto the Bahamas platform, and thus may have started as early as the late Paleocene-early Eocene. As shown below, this is consistent with the geological record in Hispaniola which does not display substantial compressive tectonics at that time, as it would be expected given the reconstructed position of the island facing a possible thrust of the SE end of the Bahamas platform (Fig 2b).

Hispaniola records some pieces of evidence of compressive tectonics in the Eocene but most of the contractional structures (folds and thrusts) formed after the middle-Eocene (Heubeck et al., 1991; Pubellier et al., 2000; Huerta \& Pérez-Estaun, 2002). Furthermore, recent geophysical imaging of the crust in western Hispaniola only suggests modest shortening (post-Cretaceous and pre-Neogene) across the Trans-Haitian belt (Corbeau et al., 2017). The lack of evidence of a major compressive event in Hispaniola during the Eocene may indicate that the collision with the Bahamas platform, if it occurred at that time, played only a minor effect on the regional tectonics or that it was mostly accommodated by a sinistral strike-slip motion. Our model setup below is based on such an assumption that the northernmost segment of the Caribbean plate was not a collisional front anymore by the early Eocene and was instead an oblique subduction-to-transform plate boundary, similar to the present-day configuration (Rodriguez-Zurrunero et al., 2020).

The position of Puerto Rico relative to Hispaniola was south or southeast in the early to mid-Eocene (Jolly et al., 2007; Pindell \& Kennan 2009). A volcanic activity of Eocene age with a geochemical signature of extensional tectonics has been reported in the southeast of Puerto Rico (Schellekens, 1991). In the northeastern part of the island, a volcanic activity is recorded up to the mid-Eocene (Jolly et al., 2007). Several lines of evidence support a transpressional (NE-SW) tectonic regime there across the Eocene (Fig. 1b). This regime mainly affected the Southern Puerto Rico Fault Zone and the Northern Puerto Rico Fault Zone which accommodated the transpression by fold-and-thrusts belts and conjugate sinistral strike-slip faults (Lao-Davila, 2012; 2014). The transpressional regime was active from the middle-Eocene to the early-Oligocene, although it may have started before (Lao-Davila et al., 2014; Roman et al., 2020). Furthermore, this regime may have been accommodated in the proxymal back arc through the formation of the east-west trending Muertos Trough and the overriding Muertos fold-and-thrust belt (Granja-Buña et al., 2009; 2014) which extends from southeast of Puerto Rico to the south of Central Hispaniola. Note that a period of contraction of Paleogene age was also reported in the Virgin Islands (St Croix) (Speed, 1989). 
Further east (or southeast), in the vicinity of the Saba bank, combined onshore and offshore geological and geophysical analysis revealed a period of compressional regime which inverted pre-mid-Eocene normal faults offshore in the region of the Saba Bank and lead to a top-to-the-W thrusting on the island of St Barthélemy dated between at least $\sim 42.5 \mathrm{Ma}$ and up to $\sim 39.7 \mathrm{Ma}$ (Philippon et al., 2020a). Put together, the above observations suggest a period of compressional and/or transpressional tectonic regime during at least part of the Eocene which affected a relatively large area of the arc/back-arc regions of the northeastern corner of the Caribbean plate (red domain, Fig. 2b).

In the central and southern part of the LASZ, the GAC occupied the present-day Aves Ridge bathymetric feature and was active until c.a. $59 \mathrm{Ma}$ (Fox et al., 1971; Neill et al., 2011; Wright \& Wyld, 2011). The opening of the Grenada basin in the southern half of the plate was contemporaneous or followed an eastwards arc migration (Bouysse et al., 1988; Pindell and Barret 1990; Allen et al., 2019; Garrocq et al., 2021). Garrocq et al., (2021) has proposed a three-stage shaping of the basin, including a NNW-SSE stretching episode during the late Paleocene-early Eocene, followed by a NW-SE oceanic spreading of at least $100 \mathrm{~km}$ which ended in the late-middle Eocene (Fig. 1c).

Based on the recent evidence on both the compressional regime at the NE corner of the Caribbean plate and the extensional regime in the region corresponding to the Grenada basin, the North-South tectonic duality of the LASZ lasted from the early Eocene to the late Eocene, thus for a duration of 10 to $20 \mathrm{Myr}$.

From the early Paleocene onwards, the southern boundary of the Caribbean plate was mainly characterized by an oblique arc-continent collision between the extinct southern-end of the GAC and South America (Pindell and Barrett, 1990; Wright \& Wyld, 2011). From the Paleocene to the early-middle Eocene, the Leeward Antilles collided obliquely with the northern Colombian margin northwest of the Maracaibo basin (Escalona and Mann 2011; Montes et al., 2019). Behind the collision front, a dextral strike-slip system to the north of the colliding extinct arc accommodated the regional transpressional regime (Beardsley \& Ave Lallemant, 2007). A net strike-slip motion involving the Oca - San Sebastian - El Pilar fault system as a part of a STEP fault may have only started in the late Eocene-early Oligocene (Escalona and Mann 2011). However, in our modeling approach, we make the case that a STEP fault-like boundary existed at the southern boundary of the Caribbean plate from the early Eocene, in consistence with the mid-Eocene reconstruction of Pindell \& Kennan (2009) (Fig. 2b).

\section{Modeling approach}

To gain insights into the tectonic evolution of the LASZ during the Eocene, we perform mechanical models of subduction using the three-dimensional version of the code ADELI (Hassani et al., 1997) which is suitable for studying the effect of the trench curvature on the state of stresses within the overriding plate (see e.g. Bonnardot et al., 2008b). In our approach (see governing equations in the Supporting 
Information), the lithospheric plates are viscoelastic solids and the mantle is treated as an inviscid fluid (Hassani et al., 1997; Buiter et al., 2001; Gibert et al., 2012). Models of subduction dynamics showed that an inviscid mantle produces results comparable to those that would be obtained with a mantle of low viscous resistance (viscosity lower than $10^{20} \mathrm{~Pa} \mathrm{~s}$ ), if the plates were sufficiently strong (viscosity ratios of about 104) (Bonnardot et al., 2008a; Cerpa et al., 2014). Furthermore, as described below, the magnitudes of plate velocities at the LASZ are relatively low, and thus we postulate that mantle drag should be moderate, at least in the shallow upper mantle. Nonetheless, mantle viscous forces may deviate the dynamics from that observed in our models and we discuss in Section 5 this limitation of our modeling approach.

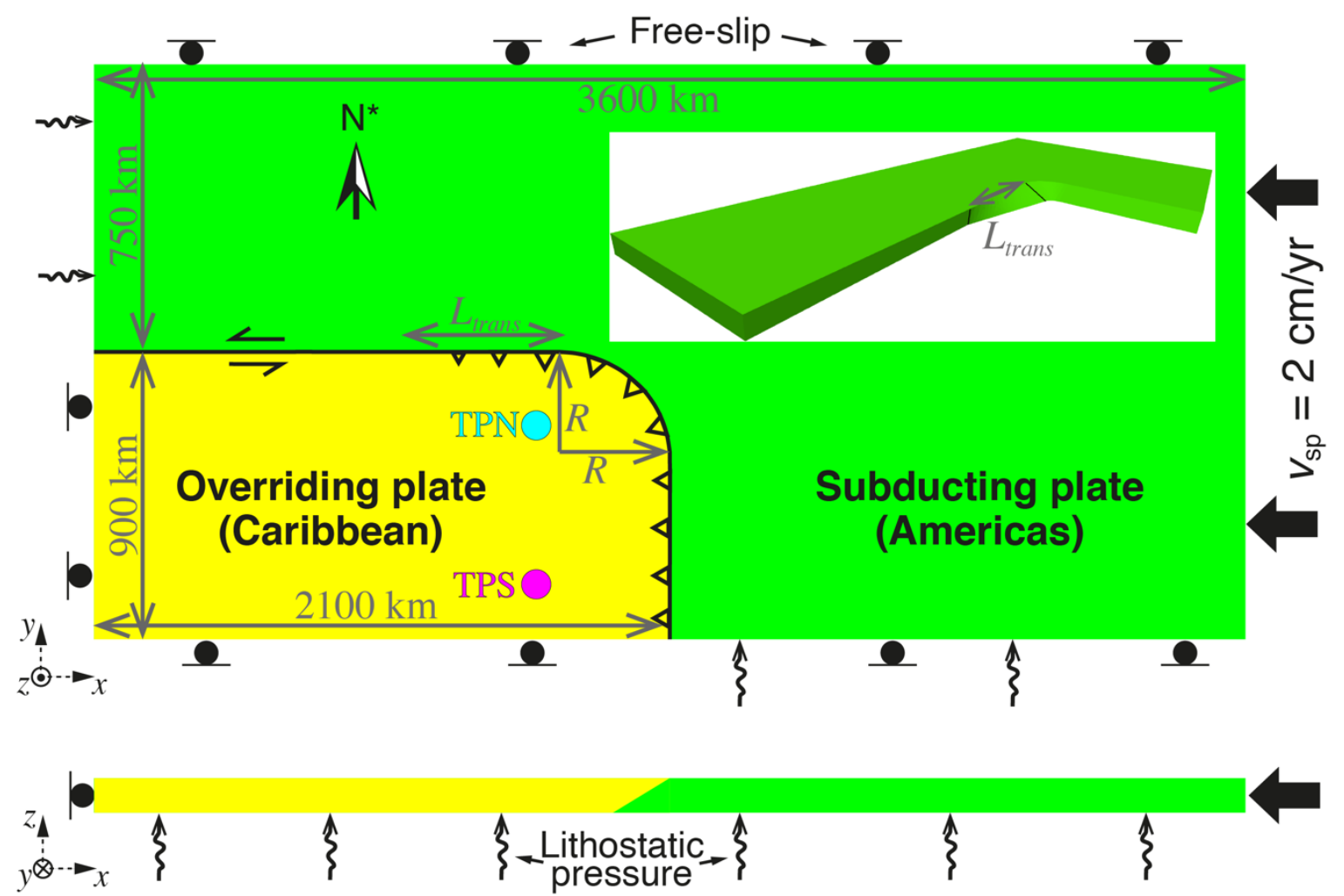

Figure 3: Initial model setup as seen from a "top-view" (top figure) and a "lateral view" (bottom), with all boundary conditions. An idealized north $\left(N^{*}\right)$ points in the same direction as the $y$-axis. Note that the southern boundary condition of the subducting plate is set to free-slip until it enters the subduction trench, after what we apply only a lithostatic pressure to simulate a STEP-like plate boundary. The inset depicts a 3-d view of the subducting plate to show the transitional plate boundary. The northern (TPN) and the southern (TPS) tracking points are used to track the evolution of the principal stresses in the idealized arc to back-arc regions.

Our models consist of two $80-\mathrm{km}$ thick homogeneous lithospheric plates initially separated by a planar fault (Fig. 3). The viscosity of the plates is $10^{24} \mathrm{~Pa}$ s and their density exceeds that of the mantle by $50 \mathrm{~kg}$ $\mathrm{m}^{-3}$. Therefore, the subducting plate has roughly the average characteristics of a 70-Ma old lithosphere, consistent with the reconstruction shown in Braszus et al., (2021) which suggest a subducted oceanic lithosphere of age between 50 and $100 \mathrm{My}$. The friction at the contact fault is set to a relatively low value 
of 0.01 , consistently with previous modeling studies who found that the shear strength at the plate interface is relatively low (Duarte et al., 2013; Behr and Becker, 2018; Crameri \& Tackely, 2015). The Young modulus and Poisson's ratio are set to average values for the lithosphere (Turcotte and Schubert, 2002), i.e. $10^{11} \mathrm{~Pa}$ and 0.25 , respectively.

The overriding plate (Caribbean Plate - CP) is $900-\mathrm{km}$ wide, which approximately corresponds to the present-day width. It is fixed at its trailing edge given that the $\mathrm{CP}$ has been roughly immobile in an absolute reference since at least $50 \mathrm{Ma}$ (Boschman et al., 2014). The velocity of the 1650-km wide (2400-km long) subducting plate (American plate - AP) is imposed at its trailing edge (Fig. 3). The latter assumption is based on the fact that the motion of the Americas was probably controlled by the eastward-dipping subduction zones occurring at their western boundary since at least the Cretaceous (Ramos 2009; Sigloch and Mihalynuk 2013) and perhaps by a large-scale mantle circulation (e.g. Faccenna et al., 2017), which must thus have controlled the velocity of the subducting plate in the LASZ. We impose the present-day value $(2 \mathrm{~cm} / \mathrm{yr})$ to the velocity of the $\mathrm{AP}$, and thus neglect the potential transient effects induced by variations in kinematics (Guillaume et al., 2018; Cerpa et al., 2018; Cerpa and Arcay 2020). The far-field kinematic boundary conditions on the plates are held from the start to the end of the models. The lateral edges of the AP are free to slip. Note that the southernmost lateral edge of the AP is let free when it plunges into the inviscid mantle, approximating a STEP fault.

The initial in-plane radius of curvature of the NE trench is set a value $R$ (Fig. 3). This is one of the most important parameters of our models. However, it is little constrained at Eocene times. We hypothesize that an increase in trench-curvature radius is a plausible scenario after the jump of the Caribbean-North America plate boundary (Early Eocene, Fig. 2a). After the jump, the new plate boundary system was indeed partly created by a cut in the former $\mathrm{CP}$ in the form of a transform fault that linked the Cayman rift/spreading axis to the eastern subduction trench (Pindell and Barrett, 1990; Boucard et al., 2021). By that time, the latter plate boundary may have been more rectilinear than at present-day (Fig. 2). We nonetheless acknowledge that the reported evidence of trench bending at the NE corner of the Caribbean plate pointed out a post-late Eocene deformation. This includes a post-Eocene $45^{\circ}$ counter-clockwise rotation of Puerto Rico (van Fossen 1989), and a post-Oligocene 15-20 counter-clockwise rotation of the St Barthelemy island (Philippon et al., 2020b) associated with a more pervasive deeply-rooting NE-SW fracturing, which fragmented the arc-forearc into a set of shallow spurs and deep valleys (Laurencin, et al., 2017; Boucard et al., 2021). Yet, it remains uncertain whether the bending of the trench was accommodated through block rotations or, instead, by a more diffuse deformational pattern, especially in regions weakened by active arc volcanism (Saba Bank, Puerto-Rico). In what follows, we explore two end-members for the trench-curvature in the models: a relatively low radius of $200 \mathrm{~km}$ and a relatively high radius of $600 \mathrm{~km}$ which is equivalent to the present-day apparent curvature of the LASZ (Fig. 1a).

Initially, the westward termination of the subduction plane ( $\left.30^{\circ} \mathrm{dip}\right)$, that is the termination of the curved trench, is at a distance $L_{\text {trans }}$ from the eastward termination of the vertical $\left(90^{\circ}\right.$ dip) transform fault (Fig. 3 inset). In between these two points the dip-angle of the contact fault between the two plates increases westwards. This transitional interplate plane is hereafter referred to as the transitional plate boundary. 
Note that during the evolution of the model, the transitional plate boundary tends to extend westwards owing to the displacement of the westernmost termination of the vertical fault on the subducting plate side, while the easternmost termination of the transitional plate boundary on the overriding plate side tends to be stationary. As seen below, such a displacement as well as the imposed initial value of $L_{\text {trans }}$ can affect the modeled state of stress, mostly in the interior of the overriding plate. Since the value of $L_{\text {trans }}$ in nature cannot be constrained otherwise than qualitatively, we explore several values.

Finally, the tectonic duality in the Eocene is mostly inferred from tectono-sedimentary observations at the surface of the LASZ, mainly located in the arc and back-arc regions. We thus focus on the modeled deviatoric stress field at the surface of the $\mathrm{CP}$ in regions situated at a distance of 150 to $400 \mathrm{~km}$ from the trench and that we refer to as the idealized arc/(proximal) back-arc regions. Note that more distal regions away from the trench are referred to as intraplate regions. In particular, for describing the arc/back-arc stress field, we define two points (Fig. 3): the Tracking Point at North (TPN) and at South (TPS) which are initially at a distance of $200 \mathrm{~km}$ from the north and south CP boundary, respectively, and at a distance of $300 \mathrm{~km}$ from the eastern trench. For simplicity, we hereafter refer the deviatoric stresses to as the stresses.

\section{Modeling results}

\subsection{Reference model}

We first consider a reference model where the trench-curvature radius is relatively low $(R=200 \mathrm{~km}$, Fig. 4). The length of the transitional plate boundary is $L_{\text {trans }}=700 \mathrm{~km}$.

All models are characterized by an initiation stage where the convergence generates compression of the overriding plate (subduction initiation). Sufficiently after the subduction-initiation stage (i.e. at $t \sim 18 \mathrm{Myr}$ ), the subducting plate sinking into the mantle is well developed, yet with some variation along the margin. At south, a "classical" subduction occurs, where the trench-normal convergence increases the length of the subducting slab with time. At the NE corner of the overriding plate, the convergence partitions between a sinking of the slab into the mantle and an E-W displacement of AP relative to CP. West of the transitional plate boundary, the relative motion between the two plates is purely strike-slip. As aforementioned, the westward termination of the transitional plate boundary moves westwards on the subducting plate side. Thus, the apparent length of the transitional plate boundary tends to increase with time.

At the model-time of $t=21 \mathrm{Myr}$ (Fig 4a), the tip of the subducting slab in the southernmost part of the model reaches a depth of $430 \mathrm{~km}$. The length of the slab in the southern part is sufficiently long (i.e. the slab pull is sufficiently high) to generate a quasi-trench normal traction on the overriding plate. We hereafter refer this force to as the trench-normal traction. The traction occurs because the slab-pull force is transmitted to the overriding plate as non-lithostatic forces acting on the subduction interface. The 
resulting extension at the surface of the overriding plate is illustrated by the principal stresses in regions lying at distances of more than $200 \mathrm{~km}$ and less than $500 \mathrm{~km}$ from the trench. There, we observe a tensile principal stress that is oriented NNW-SSE to NW-SE and rotates to W-E along the southern-free slip boundary. Thus, this principal stress is oriented towards the southernmost part of the subduction trench where the trench-normal traction is the highest. The magnitude of the tensile principal stress is about 100$150 \mathrm{MPa}$ at a distance of 200-400 km away from the trench (idealized arc/back-arc region) as illustrated at the southern-tracking point (TPS in Fig. 4c). It reaches locally $200 \mathrm{MPa}$ close to the southern boundary. Note that a compressive principal stress, with a relatively low magnitude ( 50 MPa, Fig. $4 \mathrm{c})$, is also observed in this southern-half of the CP. The magnitude of the second invariant of the stresses (J2 300 $\mathrm{MPa}$ ) along the southern boundary is controlled by both the trench-normal traction and the out-of-plane stress induced by flexure of the CP. At this stage, the tensile principal stresses in the southern back-arc area cause only moderate values of the second invariant of the deviatoric strain $\left(e_{I I}<0.05\right)$, hereafter referred to as the strain, and a negligible trench retreat (see Figure S1a,b).

Near the NE corner of the CP, we observe a region of relatively high in-plane stresses (J2>300 MPa). The high-stresses are located near the trench but reach locations as far as $300 \mathrm{~km}$ away from the interplate boundary, coinciding thus with the vicinity of the center of the curved margin. In this region, we observe principal stresses with both a NNW-SSE tensile component and an approximately WSW-ENE compressive component. The highest magnitudes of strain $\left(e_{I I} \sim 0.15\right)$ are reached in the NE corner (see Figure S1a). There, some upper plate shortening occurs and leads to a slight trench advance (see Figure $\mathrm{S} 1 \mathrm{~b})$. At the TPN, the tensile and compressive principal stresses have magnitudes of 210 and $205 \mathrm{MPa}$ (Fig. 4c) and highlight a quasi-transpressional regime in the NE corner. Moreover, this high-sheared region overlaps another patch of moderate shear $(\mathrm{J} 2 \sim 200 \mathrm{MPa})$ situated along the trench at a horizontal position $\mathrm{x} \simeq-200 \mathrm{~km}$. The latter patch of shear is induced by the indentation effect of the transitional plate boundary, as described below.

Finally, far away from the eastern subduction trench (distance of more than about $1000 \mathrm{~km}$ ), the stresses at the surface of the southern half of the overriding plate are relatively low $(\mathrm{J} 2<150 \mathrm{MPa})$ and the W-E subduction-induced tensile principal stress vanishes. Instead, a modest N-S tensile principal stress (magnitude of approximately $120 \mathrm{MPa}$ ) occurs in direction of the transform fault, and causes moderate values of strain ( $e_{I I}$ up to 0.10 , see Fig. S1a).

At $t=33.3$ Myr (Fig. 4b), the southernmost slab tip has reached a $690-\mathrm{km}$ depth. Because of the important trench-normal traction, the tensile principal stresses reach 200 to $250 \mathrm{MPa}$ in the southern half of the arc to distal back-arc region at distances from the trench of 300 to $500 \mathrm{~km}$. The point TPS displays a tensile principal stress of $206 \mathrm{MPa}$ (Fig. 4c). In the latter region, the strain now reaches moderate magnitudes of approximately $0.05-0.07$, and trench retreat at a rate of $0.2-0.3 \mathrm{~cm} / \mathrm{yr}$ (Fig. S1c,d). As in the previous stage of the model, a patch of moderate-to-high stresses ( J2 $=250-350 \mathrm{MPa})$ is observed in the vicinity of the center of the curved margin, that is in the arc/back-arc region of the NE corner of the $\mathrm{CP}$. There, we observe that the NNW-oriented tensile and the ENE-oriented compressive principal stresses 
display magnitudes of 150-200 and 150-180 MPa, respectively. The tracking point TPN exhibits tensile and compressive components with magnitudes of 192 and $146 \mathrm{MPa}$, respectively. In the NE-corner, the ratio of compressive-to-tensile principal stresses is $76 \%$ and denotes a transtensional regime.
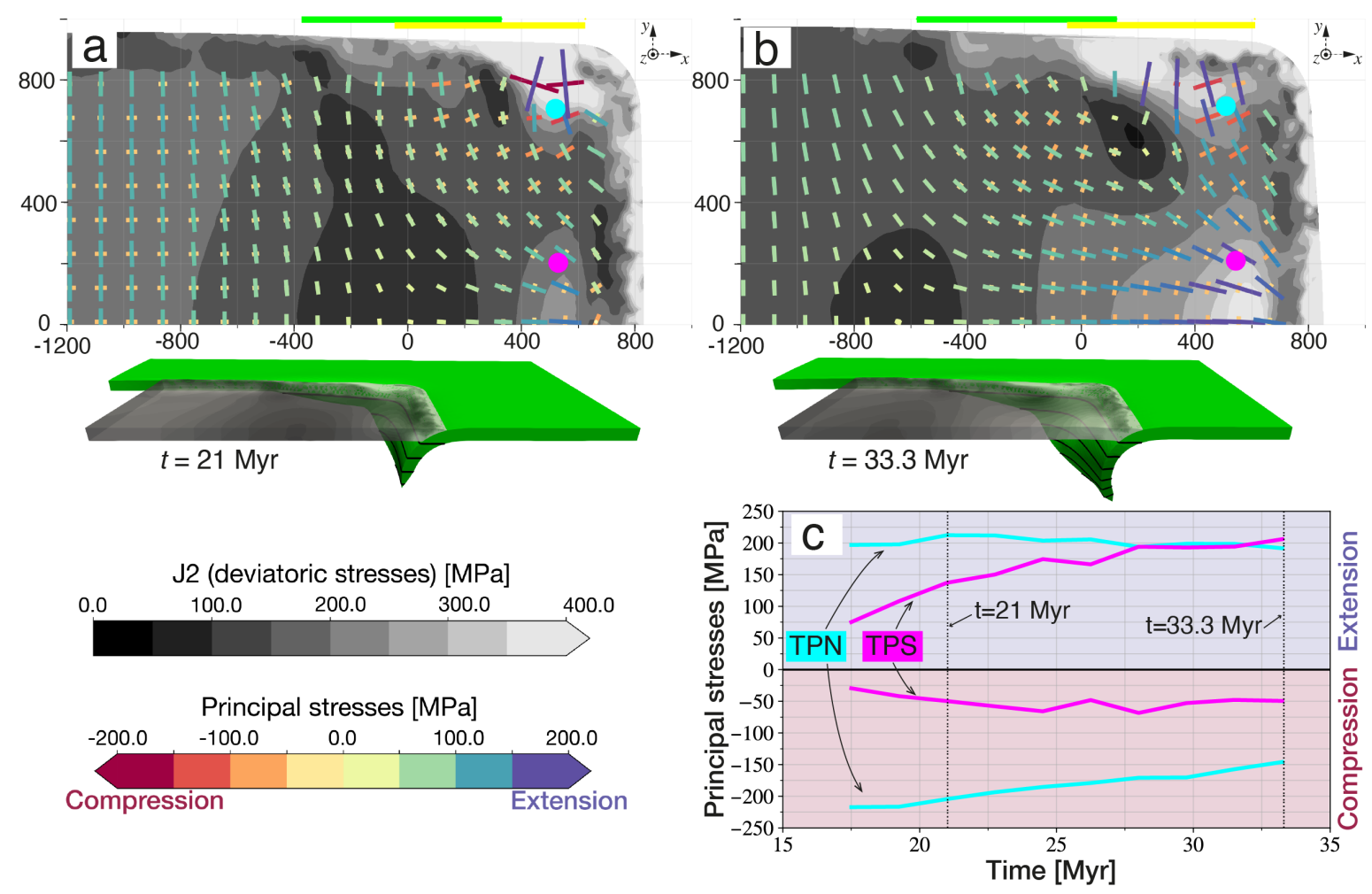

Figure $4: a$-b) Snapshots of the time-evolution of the reference model with $R=200 \mathrm{~km}(a, b)$. The gray colorscale gives the second invariant of deviatoric stresses (J2) at the surface of the overriding plate using a top view. The lines give the direction of the in-plane principal deviatoric stresses (i.e. eigenvalues of the deviatoric stress tensor or the maximum and minimum value of normal stresses) at the surface of the overriding plate, the intensity of which is given by both the red-to-blue colorscale and the segment length. Negative (redish) values are for compression and positive (bluish) values are for extension. Note that we only represent the principal stresses at distances of more than $100 \mathrm{~km}$ from the interplate boundary as we focus on the tectonic evolution of the ideal arc/back-arc region. The green and yellow rectangles above the panels indicate the horizontal extent (each rectangle has a length $L_{\text {trans }}$ ) of the geometric transitional plate boundary on both the subducting and the overriding plate sides, respectively. On the 3-d perspective view, we display depth contours every $100 \mathrm{~km}$ at the surface of the subducting plate. c) Evolution of the magnitude of the principal stresses at the two representative locations of the overriding plate tectonic regime: Tracking Point at North (TPN) in cyan and Tracking Point at South (TPS) in magenta. The point locations are also reported in the top view of the overriding plate.

At the northwest of the TPN a patch of very high stresses is visible close to the transitional plate boundary along the subducting plate side which now lies between $x \simeq-550 \mathrm{~km}$ and $x \simeq 200 \mathrm{~km}$. The stresses are particularly high $(\mathrm{J} 2>400 \mathrm{MPa})$ near the eastern end of the transitional plate boundary on the subducting plate side which is impeded to subduct and creates a local indenter acting on the subduction interface. These very high stresses remain nonetheless in a region situated at a distance of less $150 \mathrm{~km}$ away from 
the interplate boundary. Furthermore, the indentation effect of the transitional plate boundary generates some compressive principal stresses (magnitude 50-70 MPa) oriented N-S to NNE-SSW in the back-arc to intraplate regions relative to the northern transitional plate boundary (area in the ranges $x=[-400 ; 0]$ $\mathrm{km}$ and $y=[0 ; 700] \mathrm{km})$. This regions correspond lie at distances of more than 800 from the eastern trench. Farther aways from the eastern trench $(x<-400 \mathrm{~km})$ the compressive component of the principal stresses vanishes.

To sum up, at the mature stage of the reference model, four areas of varying tectonic regimes can be distinguished at the surface of the overriding plate:

1) a southern arc/back-arc region where the trench-normal traction induces WNW-oriented to NNWoriented tensile principal stresses.

2) a NE corner undergoing high stresses. This area displays a transpressive to transtensional regime that is due to the curved margin, the obliquity of subduction and the limited slab length. Note that this area undergoes a WSW-ENE-oriented compressive principal stress.

3) a back-arc to intraplate region in front of the transitional plate boundary that undergoes compressive principal stresses oriented N-S to NNE-SSW which are due to the indentation effect of the transitional plate boundary.

4) Distal intraplate regions where the stresses vanish and undergo only a small N-S oriented tensile principal stress.

\subsection{Model with a higher trench-curvature radius}

We now consider a model with a higher trench-curvature radius $(R=600 \mathrm{~km}$, Fig. 5), equivalent to that of the present-day LASZ (Fig. 1a). The transitional plate boundary initially spans the spatial range $x=$ -400 to $300 \mathrm{~km}$, and thus has the same length as that in the reference model.

At $t=21 \mathrm{Myr}$ (Fig. 5a), at south, the trench-normal traction generates a prominent (magnitude higher than $100 \mathrm{MPa}$ ) NW-oriented to E-oriented tensile principal stress in the arc/back-arc region in the southern half of the CP. For instance, the point TPS display an tensile principal stress of $140 \mathrm{MPa}$. Unlike the reference model, the second invariant of the stress do not show a substantial increase in magnitude as we approach the NE corner, and the principal stress display a little compressive component. At the point TPN the tensile and compressive components of the principal stress are 105 and $25 \mathrm{MPa}$, respectively. The region of the overriding plate that overlies the transitional plate boundary undergoes high-shear stress, especially in the vicinity of its eastern-end. Yet, the high-stress region remains within a short distance to the interplate boundary $(<150 \mathrm{~km})$.

At the model time $t=33.3 \mathrm{Myr}$, the southernmost tip of the subducting plate reaches a depth of $\sim 690$ $\mathrm{km}$. The southern long trench-normal traction exerts a relatively strong tension on the overriding plate in the arc/back-arc region both in the north and in the south, as shown by the tensile principal stress 
(magnitude $>100 \mathrm{MPa}$ ). Unlike the reference model, only modest stresses are observed at distances of more than $150 \mathrm{~km}$ from the trench in the NE corner of the CP. For instance, the point TPN displays a compressive component of $40 \mathrm{MPa}$, thus about 3 times lower that that observed in the reference model. The tensile principal stress is moderately high at the same location, displaying a value of $105 \mathrm{MPa}$, thus only two times lower than that observed in the reference model. The ratio of compressive-to-tensile principal stresses in the N-E corner is approximately $40 \%$ (in the reference model at the same stage the ratio is $76 \%$ ), and highlights a transtensional regime.

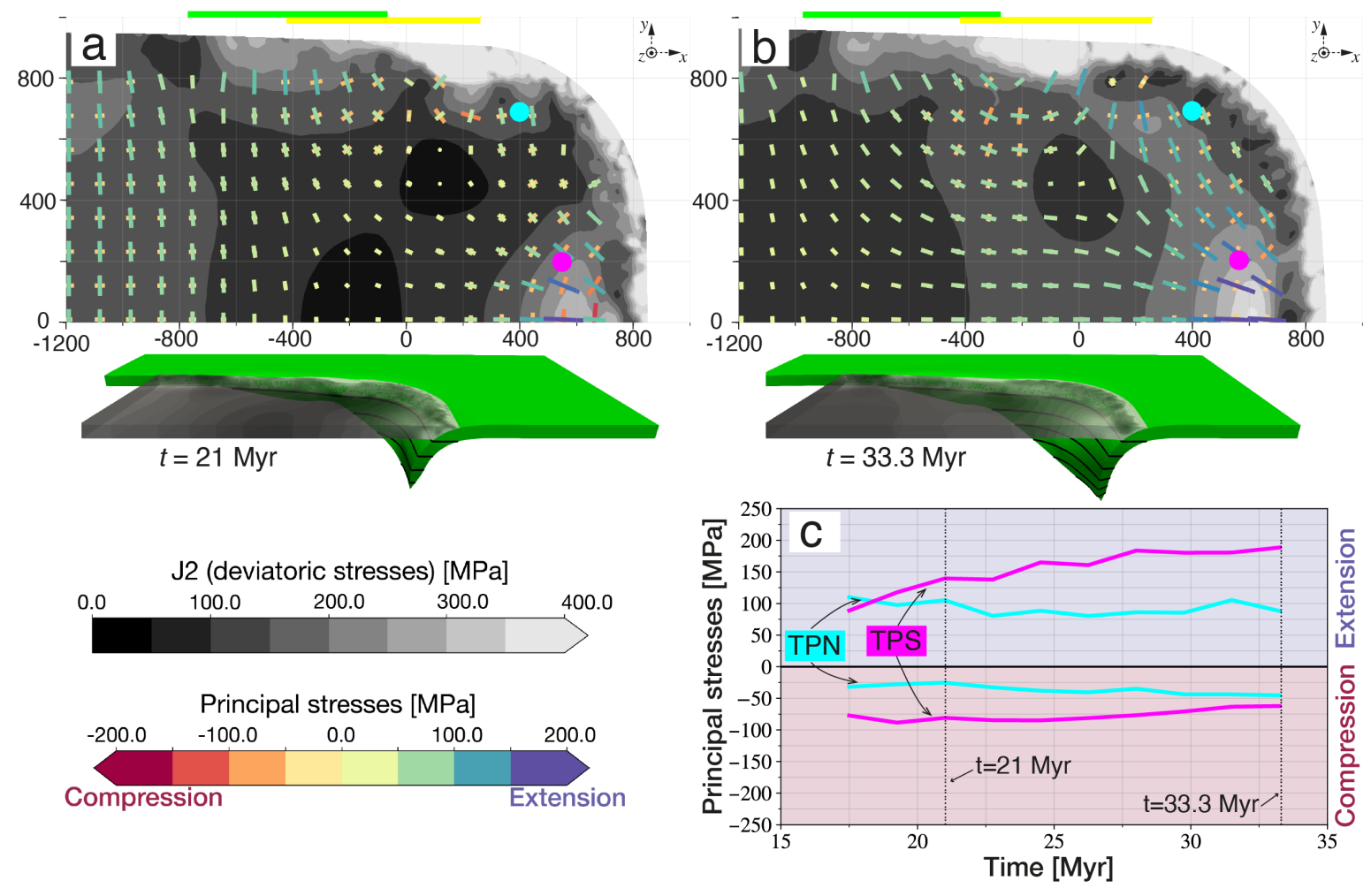

Figure 5 : $a$-b) Snapshots of the time-evolution of the reference model with $R=600 \mathrm{~km}(a, b) . c)$ Evolution of the magnitude of the principal stresses at the northern-tracking point (red) southern-tracking point (blue). The point locations are also reported in the top view of the overriding plate. For other legend details see caption of figure 4. Note that for principal deviatoric stresses negative (redish) values are for compressive stresses and positive (bluish) values are for tensile stresses.

It is important to note that in the model with $R=600 \mathrm{~km}$, we do not observe substantial a compressive principal stress in the idealized arc/back-arc region of the NE corner. That is because, in the high- $R$ model, the non-hydrostatic forces acting on the curved subduction interface converge towards a larger area compared to that in the reference model, thereby reducing the trench-normal compressive component of the principal stresses. More generally, the maximum non-hydrostatic forces acting on the overriding plate of a convex-shaped margin are inversely proportional to the trench-curvature radius, as described by Bonnardot et al., [2008]. In contrast, the magnitude of the tensile principal stress is controlled by the length 
of the southernmost subducting slab, and that is why we do not observe substantial differences between this model and the reference model.

Further north(west), the only patches of very high shear stresses are restricted to a proximal region of the transitional plate boundary. As in the reference model, this part of the interplate boundary locally indents the overriding plate, creating a NNE-oriented compressive principal stress. Yet, the latter reaches only a smaller area in the intraplate domain (in the ranges $x=[-500 ;-100] \mathrm{km}$ and $y=[400 ; 700] \mathrm{km}$ ) than in the reference model.

To summarize the mature stage $(t=33.3 \mathrm{Myr})$ of the model with $R=600 \mathrm{~km}$, we identify four distinct tectonic areas at the surface of the overriding plate:

1) a southern arc/back-arc region where the trench-normal traction induces WNW-oriented to NNWoriented tensile principal stress.

2) a NE arc/back-arc region under a transtensional/extensional regime with a tensile principal stress roughly oriented as that in the southern part. Note that the second invariant of stresses display only a moderate increase when approaching the NE corner, unlike the reference model.

3) a back arc to intraplate regions in the northern half of the plate which undergo tensile principal stresses oriented towards the eastern trench and some compressive principal stresses normal to the transitional plate boundary.

4) Distal intraplate regions where the stresses vanish and undergo only a small N-S oriented tensile principal stress.

Three of these domains are very similar to the ones simulated with a lower radius of trench-curvature $(\mathrm{R}=200 \mathrm{~km})$, i.e., areas 1, 3 and 4 . The area 2 strongly differs from its equivalent obtained in the reference model with $\mathrm{R}=200 \mathrm{~km}$, where the ratio of compressive-to-tensile principal stress is about two times higher, and denotes a regime that tends to be transpressional.

\subsection{Model with a weaker overriding plate}

We emphasize that in our modeled subduction setting, the trench-curvature radius plays an important role in the distribution of stresses at the surface of the OP. However, because in the two models presented above, the plates are relatively strong $\left(\eta=10^{24} \mathrm{~Pa} \mathrm{~s}\right)$, the radius little evolves through time. We now run a model with the same initial radius of trench-curvature as in the reference model $(R=200 \mathrm{~km})$ but with a weaker overriding plate (viscosity of $3 \times 10^{23} \mathrm{~Pa} \mathrm{~s}$ ) to increase the trench ability to bend. The overall evolution of the model with a weaker overriding plate is close to the one simulated in the reference model, except that because of its relative weakness the plate undergoes more deformation.

The compression occurring at the initial stages of subduction generates a greater shortening than in the reference model and is roughly homogeneous from North to South. At a mature stage of subduction, i.e at $t=29.2$ Myr (Fig. 6a), the southernmost slab tip reaches a depth of approximately $460 \mathrm{~km}$. The slab 
rollback induces a NNW-oriented to W-oriented tensile principal stress in the southern arc/back-arc region, as in the reference model at an equivalent stage (see Fig. 4a). The magnitude of the highest tensile principal stress is nonetheless lower than simulated in the reference model. For instance, the tensile principal stress is $64 \mathrm{MPa}$ at the TPS, whereas it reaches up to $200 \mathrm{MPa}$ in the reference model at a similar location. Such an extensional regime generates some trench retreat but at a small rate $(\sim 0.1 \mathrm{~cm} / \mathrm{yr}$, see Fig. $\mathrm{S} 2 \mathrm{~b})$. Alike the reference model, a combination of in-plane extension and compression occurs near the NE-corner of the CP. The TPN displays magnitudes of the compressive and tensile principal stresses of 70 and $85 \mathrm{MPa}$, respectively, and thus denotes a quasi-transpressional regime. More generally, in the idealized arc/back-arc area of the NE-corner, the orientation of the compressive component of the principal stresses is E-W to ENE-WSW and its magnitude is up to $150 \mathrm{MPa}$ at distance of more than 150 away from the trench. The stress field in the NE corner cause principally a E-W to ENE-WSW shortening as highlighted by the relatively high values of strain $\left(e_{I I}<0.25\right)$ and a trench westward motion at approximately $0.4 \mathrm{~cm} / \mathrm{yr}$ (FigS2a,b).

At the end of the model time ( $t=40.5 \mathrm{Myr}$, Fig. $6 \mathrm{~b}$ ), the southern tip of the subducting slab reaches a depth of $690 \mathrm{~km}$. The prominent extensional regime in the south causes important E-W stretching. This is specially illustrated by the higher values of strain achieved in the southern arc/back-arc area $\left(e_{I I}<0.10\right.$ 0.15 ) and the southern trench retreat at a rate of approximately $0.8 \mathrm{~cm} / \mathrm{yr}$ (at least twice that in the reference model) at $t=40.5 \mathrm{Myr}$ (see Fig. S2,c,d). More generally, in the model with a weaker plate, the apparent radius of trench-curvature tends to increase with time since the northernmost experiences a slightly higher E-W shortening relative to that in the reference model at the first mature stages of subduction $(t=20-25$ $\mathrm{Myr}$ ). At later mature stages of subduction ( $t>25 \mathrm{Myr}$ ), it is the southernmost part of the CP which undergoes more E-W stretching than that in the reference model.

Interestingly, we observe some decrease through time in the compressive principal stress while the tensile principal stress builds up (see e.g. Fig. 6c). The latter occurs since both the southern trench-normal traction and the apparent trench-curvature both increase. At the TPS, the tensile and compressive principal stresses are 165 and $18 \mathrm{MPa}$ respectively at $t=40.5 \mathrm{Myr}$. At the TPN, these are 135 and $80 \mathrm{MPa}$ with a ratio of compressive-to-tensile principal stresses of approximately $60 \%$. The latter value is thus intermediate between that observed in the reference model $(\sim 80 \%)$ and that in the model with a higher trench-curvature radius $(\sim 40 \%)$ for equivalent locations and at a similar stage of maturity of the subduction model.

We speculate that further trench unbending could reduce the compressive component of the principal stresses at north, and thus establish a strong transpressional regime self-consistently. However, we cannot consider models with a very weak OP (viscosity $\leq 10^{23} \mathrm{~Pa}$ ) because a too large deformation of the mesh cannot be handled without an appropriate remeshing technique which, in turn, might propagate numerical errors. 
Furthermore, in nature, the southern E-W stretching may have induced oceanic spreading (e.g. Garrocq et al., 2021) which, in turn, may have also impacted the evolution of the apparent trench curvature. This effect is however not included in our models.
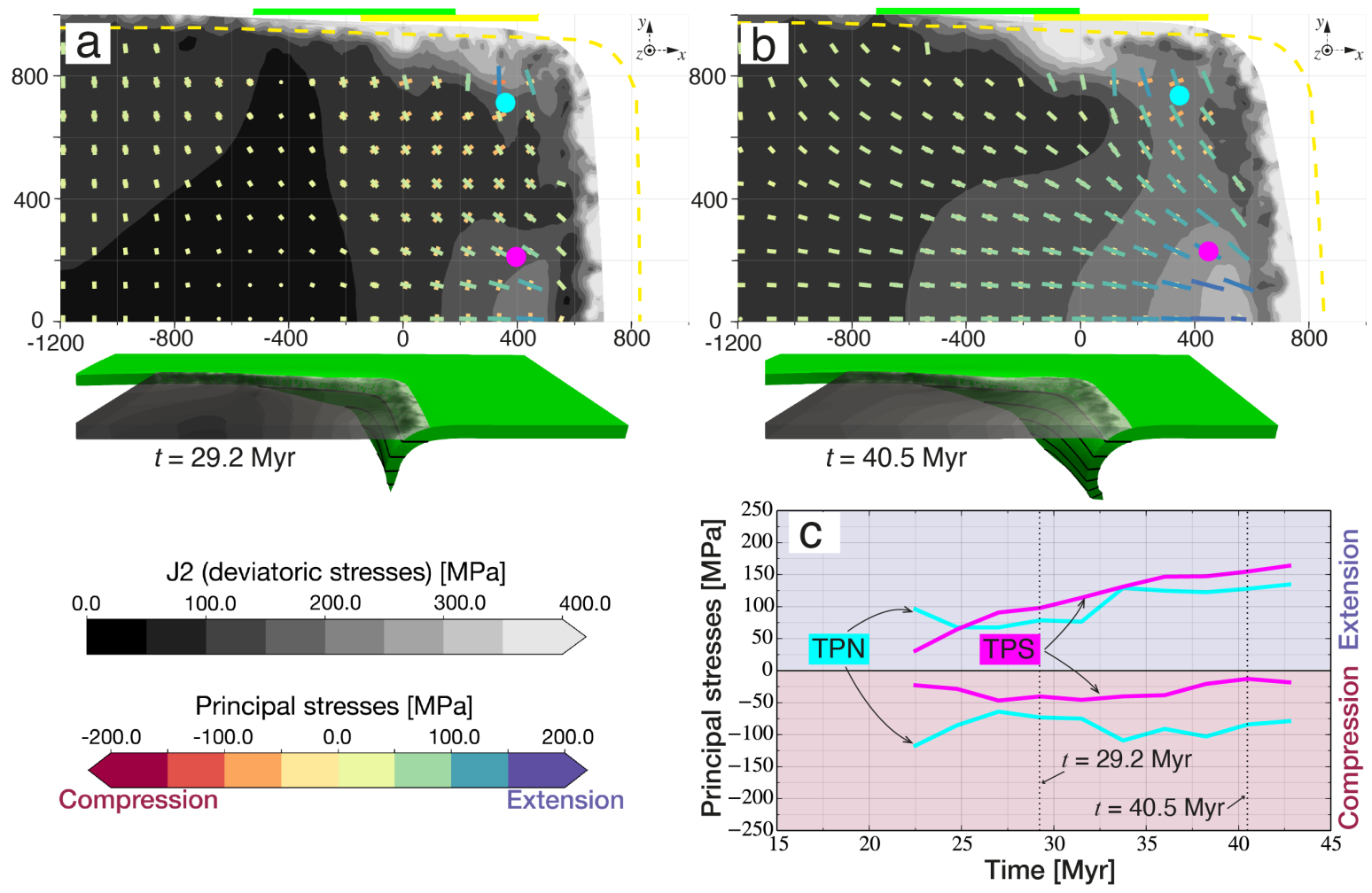

Figure 6: $a$-b) Snapshots of the time-evolution of the model performed with $R=200 \mathrm{~km}$ and with a weaker overriding plate (viscosity of $3 \times 10^{23} \mathrm{~Pa} \mathrm{~s}$ ) than the reference model. The dashed yellow lines display the shape of the overriding plate in the reference model at equivalent stages of subduction (different times but with the same depth reached by the southernmost slab tip). See Figure 4 for other legend details. Note that for principal deviatoric stresses negative (redish) values are for compressive stresses and positive (bluish) values are for tensile stresses.

4.4 Models with various initial lengths of the transitional plate boundary

We have highlighted the effect of the transitional plate boundary on the state of stresses close to the boundary as well as in the intraplate domain. Because there is no accurate constraint on its length in nature for the Eocene, and because it might have changed through time, here, we explore models with different lengths. Two models are considered with values of $L_{\text {trans }}$ lower (400 km; Fig. 7a,b) and higher (1150 km; Fig. $7 \mathrm{c}, \mathrm{d})$ than that of the reference model $(700 \mathrm{~km})$. 
At the end of the simulations ( $t=33.3 \mathrm{Myr}$ - mature stage of subduction), the tectonic regime in the arc/back-arc region is equivalent in both models with $L_{\text {trans }}=400 \mathrm{~km}$ and $L_{\text {trans }}=1150 \mathrm{~km}$. The southern part undergoes extensional regime and the northern part undergoes transpressional regime. The magnitude of the former is similar in both cases at the TPS which display a dominant tensile principal stress of about $210 \mathrm{MPa}$. The latter is equivalent in both models as they display a ratio of compressive-totensile principal stresses of approximately $80 \%$. This ratio is identical to that in the reference model, although the compressive component has a lower magnitude $(130 \mathrm{MPa})$ in the model with $L_{\text {trans }}=400$ $\mathrm{km}$ than in the reference model $(145 \mathrm{MPa})$ and in the model with $L_{\text {trans }}=1150 \mathrm{~km}(150 \mathrm{MPa})$.
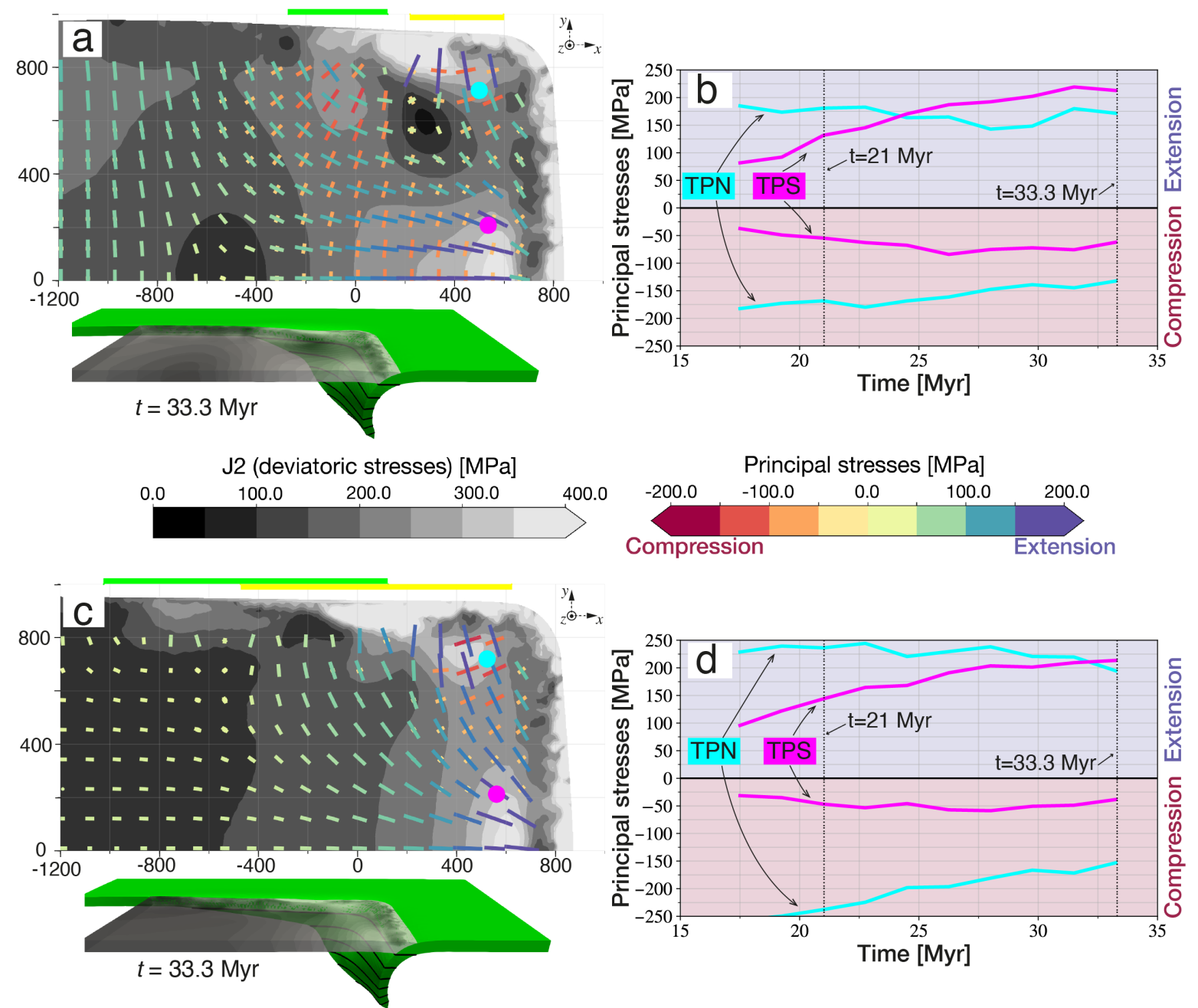

Figure 7: Stress field at the end of the model time in the models with a lower $\left(L_{\text {trans }}=400 \mathrm{~km} ;\right.$ a,b) and a higher $\left(L_{\text {trans }}=1150 \mathrm{~km} ; c, d\right)$ length of the transitional plate boundary than the reference model. See Figure 4 for other legend details. Note that for principal deviatoric stresses negative (redish) values are for compressive stresses and positive (bluish) values are for tensile stresses

The two models exhibit moderate (J2>200 MPa) to very high stresses (J2>400 MPa) along the transitional plate boundary. In particular, a patch of very high stresses is always located either close or east of the eastern-end of the transitional plate boundary (see green rectangles in Fig. 7a,c) but remains within a 
distances shorter than $100 \mathrm{~km}$ from this boundary. This high-stress area has a little influence on the tectonic regime in the NE corner which is controlled by the trench-curvature radius.

The major effect of changing the length of the transitional plate boundary is on the stress field in the backarc to intraplate regions. The smallest value of $L_{\text {trans }}$ induces a N-S to NE-SW oriented compressive component of the principal stresses with a moderate-to-high magnitude (80 to $120 \mathrm{MPa}$ ) in this area (roughly between $x=-400$ and $200 \mathrm{~km}$ ) that faces the transitional plate boundary. We refer this effect to as an indenter-effect induced by the geometry of the transitional plate boundary which impedes subduction. The compressive principal stress in the back-arc to intraplate areas remains however lower than that in the arc/back-arc NE corner of the same model. In the model with the highest values of $L_{\text {trans }}$, such a compressive principal stress vanishes.

\section{Discussion}

\subsection{Application to the tectonic duality during the Eocene}

The main results presented above which are relevant for the comparison with the tectonic regime in the LASZ during the Eocene are:

- In the context of an asymmetrical subduction zone bounded by a STEP fault at the south and a transition from subduction-to-strike slip at the north, the high trench-normal traction adjacent to the STEP-fault provokes tensile stresses at the surface of the overriding plate (oriented from NNWSSE to W-E) in the southern portion of the margin at distances from the trench between 150 and beyond $400 \mathrm{~km}$, thus ideally comprising the arc and back-arc regions.

- At the NE-trench corner, the trench curvature controls the obliquity of subduction. The obliquity hampers the lengthening of the subducting slab and hence the associated trench-normal traction.

- In the arcuate part of the subduction zone, the non-lithostatic forces transmitted by the subducting slab to the overriding plate through the subduction interface tend to converge towards the center of the curved trench. Depending on the trench-curvature radius, this induces different tectonic regimes at the $\mathrm{NE}$ corner of the $\mathrm{CP}$ :

$\circ$ When the trench-curvature radius is relatively low, the idealized arc/back-arc regions can undergo a compressive principal stress oriented E-W to ENE-WSW. The ratio of compressive-to-tensile principal stresses is relatively high $(>60 \%)$ and denotes a tectonic regime that tends to be transpressional.

- When the trench-curvature radius is relatively high, comparable to the present-day radius of curvature of the LASZ, the compressive component of the principal stresses is limited. 
The ratio of compressive-to-tensile principal stresses is less than $40 \%$ and denotes a clear transtensional regime.

- If the overriding plate is sufficiently weak, the trench-curvature radius can self-consistently increase through time according to the related stress field. In particular, some W-E stretching in the southernmost portions of the CP occurs. As a consequence, in the NE-corner, the compressive component of the principal stresses is progressively relieved.

- At north, the westward displacement of the transitional plate boundary, which connects the eastern subduction contact fault to the western transform fault, induces high shear stresses in the idealized forearc area. The transitional plate boundary also acts as an indenter on the overriding plate and can induce a N-to-NE oriented compressive principal stress in the back-arc to intraplate area. This indenter-effect is approximately inversely proportional to the length of the transitional plate boundary.
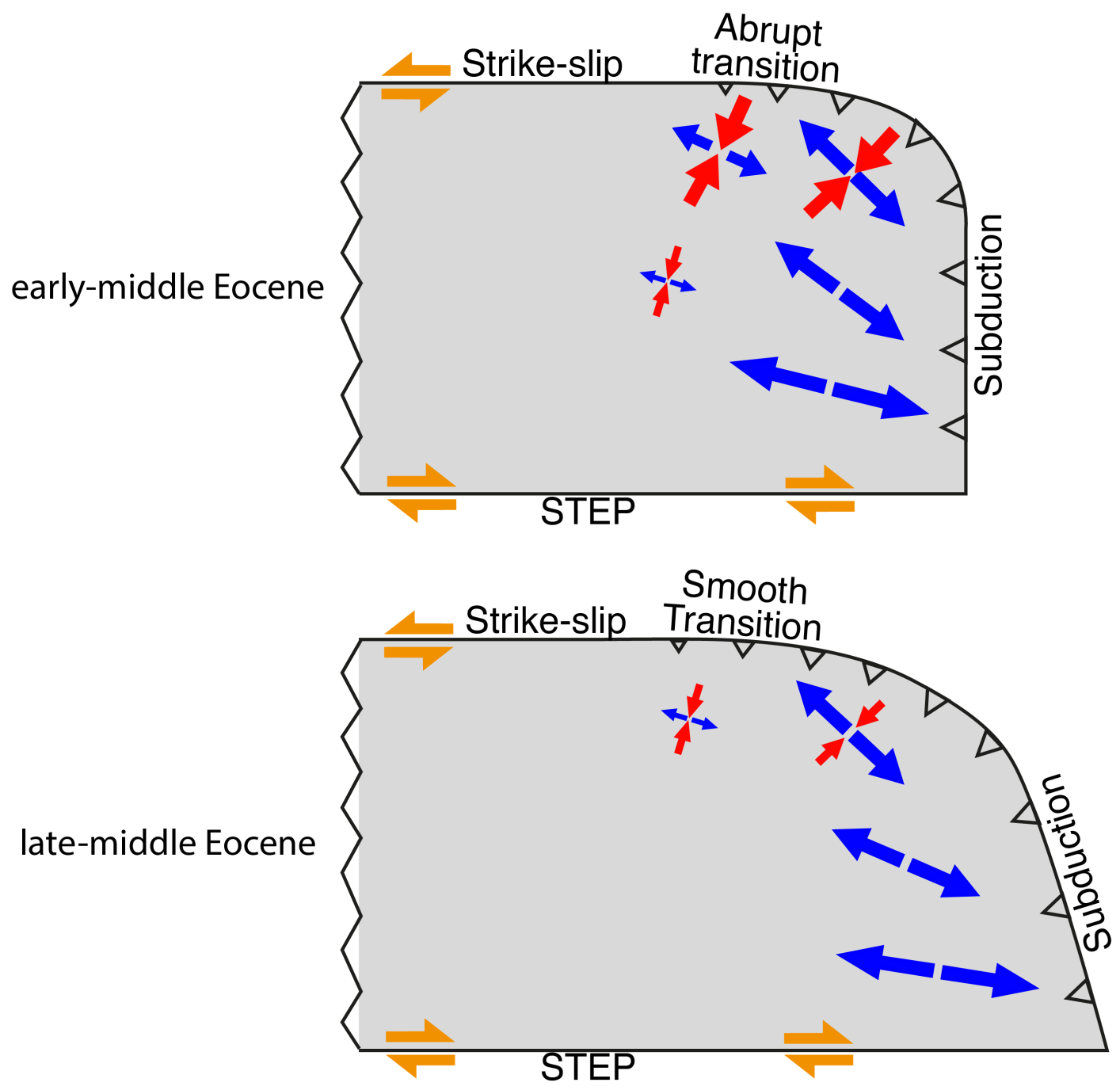
Figure 8: Sketch of our tectonic model for the spatio-temporal evolution of the tectonic regime in the back-arc of the LASZ during the Eocene

Based on our modeling results, we suggest that the trench curvature of the LASZ, as well as the northern strike-slip and southern STEP boundaries, were major contributors to the evolution of the tectonic stresses in the arc and back-arc regions of the eastern Caribbean plate (Fig. 8). Back in the early to middle Eocene (from approximately $\sim 55-50 \mathrm{Ma}$ to $\sim 40-35 \mathrm{Ma}$ ), we hypothesize that the radius of trench curvature in the $\mathrm{NE}$ corner of the plate was relatively low $(\mathrm{R}<<600 \mathrm{~km})$. This promoted a transpressional regime in the the vicinity of the highly-arcuated trench and corresponding to the region overlying the obliquely subducting plate which comprised from east to west : the Saba Bank, the Virgin Islands and Puerto-Rico. We note however that in our models the compressive component of principal stresses in the NE corner equals, at most, the tensile component. Other factors may thus be required to induce a dominant compressive component. As discussed below, the arrival of a buoyant feature such as the Bahamas bank may have played such a role. In the south, our models suggest that the rollback of the South American oceanic subducting slab may have assisted the opening of the Grenada basin by generating tensile stresses pointing towards the southern parts of the subduction trench, which is consistent with the direction of oceanic spreading suggested by previous studies (Bouysse et al., 1988; Aitken et al., 2011; Garrocq et al., 2021).

Note that just after the jump in the plate boundary between the CP and the NAM, the transitional plate boundary might have been of a reduced length, and might also have helped to reach the conditions of a transpressional tectonic regime in the back-arc and intraplate areas.

From the middle Eocene onwards, the trench-curvature radius may have increased and caused a relief in the tectonic stresses at the NE corner of the Caribbean plate. This may have facilitated the cessation of transpression in the NE Lesser Antilles by the late Eocene. Part of the increase in the apparent trenchcurvature radius may have self-consistenly been induced by the deformation of the Caribbean plate under the North-South varying tectonic regime, as in our model with a weak OP. Alternatively, the accretion of oceanic crust in the Grenada basin during the middle Eocene might also have increased the apparent trench-curvature radius.

A shift in the tectonic regime of the arc/back-arc of the Lesser Antilles occurred in the late Eocene to early Oligocene period, causing SW-NE extension in the north (Legendre et al., 2018; Cornée et al., 2021) and the end of spreading in the Grenada basin (Garrocq et al., 2021, Fig. 1c). Our models do not address the cause of this tectonic reorganization. 
5.2 Other implications for the tectonic evolution during the Eocene

Besides addressing a possible (simple) mechanism for explaining the Eocene-tectonic duality in the LASZ, our models may also shed light on other geological and paleogeographic observations in the region.

Garrocq et al., (2021) have proposed two extensive phases that shaped the Grenada basin from the early to the middle Eocene: a rifting and a spreading stage. The authors proposed a consistent NW-SE direction of extension through both stages. Their spreading direction is compatible with a possible NW-dipping subduction of the Atlantic seafloor in the southernmost part of the LASZ, as suggested by previous tectonic reconstructions (e.g. Pindell and Kennan, 2009). Our models suggest instead that the NW-SE rifting and spreading episodes may also be compatible with a more $\mathrm{W}$-dipping subducting slab. The latter case may therefore be compatible with the approximately N-S oriented outer arc inferred from magnetic anomalies east of the Tobago Basin and which might be Eocene in age (Allen et al., 2019).

The underthrusting of the Venezuela Basin beneath Puerto Rico and Hispaniola at the Muertos Trough accommodated a relative, probably modest (Boschman et al., 2014), convergence between the Caribbean and the North American plates (Fig. 1). The estimated date of formation of the Muertos Trough and the associated thrust deformed belt varies between the Cretaceous (Byrne et al., 1985) and the Miocene (Mann et al., 2002) but several studies have pointed out a possible start at Eocene Times (Mauffret and Leroy 1999; Leroy et al., 2000; Granja-Bruña et al., 2014). It has been generally proposed that the arrival of the buoyant Bahamas platform at the Puerto Rico trench was the trigger of the formation of the thrust belt (Mann et al., 2002; Granja-Bruña et al., 2009; ten Brink et al. 2009). Our models suggest an alternative mechanism in which the intraplate region facing the northern transitional plate boundary undergoes a Nto-NE oriented compression. Furthermore, the modeled magnitude of the latter displays an inversely proportional relationship to the length of the transitional plate boundary. Although its length is unknown in the natural case at Eocene times, one may hypothesize that following the jump in the plate boundary (from NE Cuba to $\mathrm{N}$ of the Greater Antilles, Fig. 2a) this transition was quite sharp. It follows that intraplate compression might have affected the north of the Venezuela Basin in the early to middle-Eocene and might have been accommodated through its underthrust at the Muertos Trough, releasing the compression at farther distances. At later times, the possible increase in the length of the transitional plate boundary may have limited this compressive component.

According to our models, two tectonic regimes may have coexisted during the Eocene in the arc/back-arc regions of northeastern and northern LASZ. In the former, a transpressional regime may have held in the arcuate NE corner for as long as the trench-curvature radius was relatively low. Slightly west of the NE corner another regional transpressional regime may have resulted from a sharp transitional plate boundary. Based on our modeling, we expect the two areas experiencing the most prominent transpressional regime to slightly migrate westwards through time mostly because of the westward displacement of the transitional plate boundary. As discussed above, following accommodation of inland compression at the 
Muertos Trough and an increase in the trench-curvature radius, the westward migration of transpression may have been coeval of a strong reduction in the magnitude of the compressive component of the stresses by the late Eocene. We nonetheless acknowledge the existence of evidence for an eastward migration of compressive stresses instead, as recorded by crustal exhumation episodes of decreasing age from Cuba to Puerto Rico (Roman et al., 2020). This eastward migration of compressive events is often regarded as the consequence of the eastward migrating front of the collision with the Bahamas bank which started in Cuba in the Paleocene (Roman et al., 2020). As discussed below, our proposed mechanism may be an additional process to take into account for understanding the geodynamical evolution of the northern Caribbean. Nevertheless, our models also suffer from other few limitations which we discuss in the next subsection.

A major tectonic event is thought to have occurred during the Eocene which may have caused the rise and the demise of a land bridge in the arc or back-arc areas, thus corresponding to the Aves Ridge (GAARlandia hypothesis, Iturralde-Vinent and MacPhee, 1999), thereby allowing for the dispersal of terrestrial fauna from South America to the Greater Antilles (e.g. Marivaux et al., 2020). However, this paleogeographic model has been regarded as controversial (e.g. Ali et al., 2012). Recently, Philippon et al., (2020a) provided geological evidence that advocates for a geodynamical-triggerred regional uplift consistent with the GAARlandia hypothesis (see also Cornée et al., 2021). They showed that the period of shortening in the arc/back-arc of the Northern Lesser Antilles was indeed associated to a regional uplift in the middle to late Eocene (emersion of the GraNoLA land) and suggested that the compressional event was triggered by a plate-kinematics reconfiguration. Our study provides an alternative geodynamical mechanism that may have helped to form emerged lands and later assisted their subsidence in the NE corner of the Lesser Antilles. It is a step forward in trying to connect deep-solid Earth dynamics and surface biogeographical evolution in the eastern Caribbean. Further studies are nonetheless required to decipher what caused a transient-period of uplift in the southern parts (Aves Ridge) which may have permitted the fauna dispersal from South America to the north-eastern Caribbean.

\subsection{Model limitations}

\subsubsection{Assumption of an inviscid mantle}

In our modeling approach, we only take into account the effect of the ambient mantle through the density contrast (Forsyth and Uyeda, 1975). A viscous mantle may however exert both normal stresses induced and shear stresses on the plates-mantle interface (Tovish et al., 1978; Funiciello et al., 2003; Lallemand et al., 2008; Royden \& Holt, 2020). In particular, the toroidal flow, that is the horizontal-component of upper mantle flow occurring around the edges of the subducting plate from the rear of the slab towards the front of the slab (Funiciello 2003; Schellart et al., 2004), induces shear stresses at the base of the plates and may facilitate back-arc opening (Schellart and Moresi 2013; Chen et al., 2016; Alsaif et al., 2020). In the Caribbean, a toroidal flow around the southern termination of the American subducting plate might have favored the opening of the Grenada basin, while a more oblique subduction at north may have impeded it, thus facilitating a latitudinal duality of surface tectonics. We hypothesize that this effect, if of a sufficient magnitude, would thus have reinforced the tectonic duality observed in our models, but would not have 
drastically changed the first-order trends in the stress field. In addition, mantle resistance to slab rollback and induced toroidal flow around slab edges have been suggested to promote a SP-wards concave subducting slab shape at mid-upper mantle depths (Schellart et al., 2007). It is possible that such a deformation could have enhanced the unbending of the LASZ trench. Yet, laboratory analog models have shown that this effect might be minored for relatively narrow subduction zones such as the LASZ (Guillaume et al., 2021). Finally, it is noteworthy to mention that present-day upper mantle flow inferred from regional seismic anisotropy does not resemble to a classical toroidal flow beneath the eastern boundary of the Caribbean plate (Zhu et al., 2020). This may be due to the nearby presence of much larger subduction zones, such as the Andean subduction zone, which may affect the background mantle flow in the vicinity of the LASZ (Russo and Silver, 1994). Back in time, the background mantle flow is unknown and thus strong assumptions would have been needed for carrying out an accurate regional modeling. Overall, the modeling approach that we undertake, although neglecting the ambient upper mantle flow, offers a useful approximation of the forces transmitted by the subducting slab to the overriding plate and the induced overriding plate surface tectonics. The evolution through time of the trench-curvature radius in our models arising from the stress field, might be a lower estimation because of the neglection of the upper-mantle three dimensional flow.

Besides the effect of upper mantle flow, another potential caveat of our models is that we neglect the interaction of the subducting slab with the upper-lower mantle discontinuity at a $660-\mathrm{km}$ depth. To date, no consensus exists on the subducting slab shape beneath the LASZ at and through the $600-\mathrm{km}$ discontinuity since regional tomography has suggested both that the slab lies on top of the $660-\mathrm{km}$ depth (von Benthem et al., 2013) and that its has penetrated into the lower mantle (Braszus et al., 2021). The latter scenario may diverge the most from the modeled geodynamical evolution in our study. Indeed, a viscosity increase at the 660-km discontinuity hampers the slab sinking and can lead to its vertical buckling and folding atop and through the discontinuity (Lee et al., 2011; Garel et al., 2014; Agrusta et al., 2017). Slab folding may, in turn, affect the overriding plate tectonics, producing alternate periods of compression and extension in the back-arc as shown in models of straight subduction zones (Lee et al., 2011; Cerpa et al., 2014, 2015; Boutoux et al., 2021). To our knowledge, there is no study that has quantified the impact of slab folding at the 660 in the context of highly arcuate subduction zones. Thus, we only can hypothesize how slab folding might have affected the more straighter southern part of the LASZ. It is indeed possible that the extensional regime that we observe in our models and that we relate to the period of stretching and spreading in the Grenada basin, was coeval of the backward (SP-wards) motion of slab fold. The forward (OP-wards) motion of the slab fold might have provoked the reversal of the extensional tectonic regime and thus lead to the halt of back-arc spreading. Further modeling studies would be required to address this scenario if the penetration of the Lesser Antilles subducting slab into the lower mantle during the Eocene was confirmed. 


\subsubsection{Structural heterogeneities within the Caribbean Plate}

At present-day, the north-eastern Caribbean crust has a thickness of $\sim 25$ to up to $\sim 35 \mathrm{~km}$ from the backarc to the forearc (Kopp et al., 2011; Melekhova et al., 2019; Padron et al., 2021). The southern-eastern part of the $\mathrm{CP}$ is characterized by the presence of a thin $(5-10 \mathrm{~km})$ oceanic crust in the Grenada and Tobago basins (Fig. 1) (Christeson et al., 2008; Padron et al., 2021), separated by the post-mid Eocene volcanic arc-crust, that reaches a thickness of 29-33 km beneath the arc islands (Melehkova et al., 2019). West of the Grenada basin, the Aves Ridge has an average thickness of $\sim 25 \mathrm{~km}$ comparable with the northern crust (Christeson et al., 2008; Padron et al., 2021). Prior to the rifting episode which triggered the Grenada basin opening, the Caribbean crust might have been more homogeneous along the active arc. The rifting and the oceanic spreading likely induced spatio-temporal variations in the strength of the Caribbean plate from North to South. This may have reinforced the dual tectonic evolution of the Caribbean plate. In contrast, in our models, the homogeneous strength of the overriding plate cannot evolve nor in space neither with time. Moreover, the localization of tectonic deformations nearby the spreading center during the Eocene may have limited the transmission of stresses within the CP. If such a process was included in our models, we would expect it to hamper the NNW-oriented extension (due to the southern trench-normal traction) observed in the NE corner of our modeled $\mathrm{CP}$, and to promote a dominant transtensional regime in this area.

\subsection{Effect of the subduction-collision of the Bahamas bank}

We have not directly addressed the potential effect of the collision of the northern Caribbean plate with the buoyant Bahamas platform (apart our working assumption of a plate boundary jump in the Late Paleocene). Such a collision in Cuba is thought to have played a major role in the tectonic evolution of this region in the Paleocene - early Eocene, inducing ultimately a re-organization of the North America Caribbean plate boundary. However, the effect of a possible (south)east-ward propagation of the collision front is yet to be determined. For instance, the arrival of the SE-end of the Bahamas platform into the subduction trench facing Puerto-Rico, was suggested to trigger a transpressional regime in the middle to late Eocene (Lao-Davila et al., 2012; 2014; Román et al., 2020). In fact, Wallace et al (2005) and Wallace et al., (2009) proposed a model for the tectonics nearby a transition from collision-to-subduction. In their model, the arrival of a buoyant feature (collision) generates the bending of the margin, and induces prominent compression in the regions facing the collisional segment while potentially inducing back-arc rifting away from the collision. The latter occurs as the bending of the margin is accompanied by a continued slab-rollback which is accommodated by the rotation of micro-forearc blocks. The model has been recently invoked by Philippon et al., (2020b) and Boucard et al., (2021) to explain the formation of $\mathrm{V}$-shaped forearc basins after the late Eocene. 
Whether Wallace et al.'s model could explain the evolution of the LASZ for the entire Eocene remains an open question. The records of compression in Hispaniola indeed points out to a "soft collision" (i.e. leaving few markers of compression, see Section 2), if at all induced by the subduction of the Bahamas platform (van Benthem et al., 2014). Similarly, the record of a rather soft-collisional environment in Puerto-Rico during the Eocene, lead Lao-Davila et al., (2014) to propose that the nature of the buoyant feature entering the subduction trench was a thickened oceanic crust. It is worth noting that the underthrusting of the SE-continuation of the platform offshore Puerto-Rico has also been proposed to take place only later in the Miocene (Mann et al., 2002; Grindlay et al., 2005).

Here, we suggest that the effect of the Bahamas collision, if it occurred at Eocene times, may have been, at least, largely assisted by the effect of a nearby subduction zone under a highly curved trench and perhaps also by the indenter effect induced by a transitional plate boundary. This hypothesis is in line with the work of van Benthem et al., (2014) who proposed that a force exerted by the along-strike displacement of the western-edge of the slab (a "slab edge push") beneath the northern Caribbean plate boundary was the main driver of regional tectonics, and exceeded the effect of the Bahamas platform collision. Although these authors assumed that the Bahamas subduction only started in the Oligocene onwards, a similar force balance may have occurred if the subduction of the platform occurred earlier. Further work should nonetheless be carried out to quantify the joint effect of a (soft-)collision nearby a transitional plate boundary and a time-evolving curved subduction trench.

\section{Conclusions}

Recent studies have shed light on a singular tectonic regime in the arc/back-arc region of the LASZ for at least part of the Eocene. While the southernmost part underwent stretching in the Grenada basin, the northern part underwent thrusting and shortening under compressional and/or transpressional tectonic regime. Our mechanical models of subduction suggest that this Eocene-tectonic duality may have been generated by both a relatively low trench-curvature radius at the NE-corner of the Caribbean plate in the context of asymmetrical Caribbean plate boundaries at the North (from east to west: highly oblique subduction to a strike-slip system) and at the South (a STEP-like boundary). A compressional/transpressional regime at north and an extensional regime at south may have resulted in an increase in the apparent trench-curvature radius, especially if tensile stresses were accommodated by oceanic spreading at South. Our models suggest that trench unbending, i.e. the increase in the trenchcurvature radius, could have relieved the compressive stresses in the northern part through time.

\section{Acknowledgments}

This work was supported by the GAARAnti project (ANR-17-31 CE-0009). The authors thank the technical and scientific teams of cruises AntiTheSis and GARAnti for data acquisition and research findings, which have motivated this study. All models were run on the HPC Platform MESO@LR, financed by the Occitanie / Pyrénées-Méditerranée Region, Montpellier Mediterranean Metropole and the University of Montpellier. 


\section{Data Availability Statement}

The structural data (Fig. 1) used in our work is from published studies (Philippon et al., 2020a; Garrocq et al., 2021) which provide the details on how to access their publicly available data. 


\section{References}

Agrusta, R., Goes, S., \& Van Hunen, J. (2017). Subducting-slab transition-zone interaction: Stagnation, penetration and mode switches. Earth and Planetary Science Letters, 464, 10-23

Aitken, T., Mann, P., Escalona, A., \& Christeson, G. L. (2011). Evolution of the Grenada and Tobago basins and implications for arc migration. Marine and Petroleum Geology, 28(1), 235-258.

Ali, J. R. (2012). Colonizing the Caribbean: is the GAARlandia land-bridge hypothesis gaining a foothold?. Journal of Biogeography, 39(3), 431-433. doi: 10.1111/j.1365-2699.2011.02674.x

Allen, R. W., Collier, J. S., Stewart, A. G., Henstock, T., Goes, S., Rietbrock, A., \& VoiLA Team. (2019). The role of arc migration in the development of the Lesser Antilles: A new tectonic model for the Cenozoic evolution of the eastern Caribbean. Geology, 47(9), 891-895.

Alsaif, M., Garel, F., Gueydan, F., \& Davies, D. R. (2020). Upper plate deformation and trench retreat modulated by subduction-driven shallow asthenospheric flows. Earth and Planetary Science Letters, 532, 116013.

Beardsley, A. G., \& Avé Lallemant, H. G. (2007). Oblique collision and accretion of the Netherlands Leeward Antilles to South America. Tectonics, 26(2).

Behr, W. M., \& Becker, T. W. (2018). Sediment control on subduction plate speeds. Earth and Planetary Science Letters, 502, 166-173.

Bonnardot, M. A., Hassani, R., \& Tric, E. (2008a). Numerical modelling of lithosphere-asthenosphere interaction in a subduction zone. Earth and Planetary Science Letters, 272(3-4), 698-708.

Bonnardot, M. A., Hassani, R., Tric, E., Ruellan, E., \& Régnier, M. (2008b). Effect of margin curvature on plate deformation in a 3-D numerical model of subduction zones. Geophysical Journal International, 173(3), 1084-1094.

Boschman, L. M., van Hinsbergen, D. J., Torsvik, T. H., Spakman, W., \& Pindell, J. L. (2014). Kinematic reconstruction of the Caribbean region since the early Jurassic. Earth-Science Reviews, 138, 102-136.

Boucard, M., Marcaillou, B., Lebrun, J. F., Laurencin, M., Klingelhoefer, F., Laigle, M., ... \& Philippon, M. (2021). Paleogene V-Shaped Basins and Neogene Subsidence of the Northern Lesser Antilles Forearc. Tectonics, 40(3), e2020TC006524.

Boutelier, D. A., \& Oncken, O. (2010). Role of the plate margin curvature in the plateau buildup: Consequences for the central Andes. Journal of Geophysical Research: Solid Earth, 115(B4).

Boutoux, A., Briaud, A., Faccenna, C., Ballato, P., Rossetti, F., \& Blanc, E. (2021). Slab folding and surface deformation of the Iran mobile belt. Tectonics, 40(6), e2020TC006300.

Bouysse, P. (1988). Opening of the Grenada back-arc basin and evolution of the Caribbean plate during the Mesozoic and early Paleogene. Tectonophysics, 149(1-2), 121-143.

Bralower, T. J., \& Iturralde-Vinent, M. A. (1997). Micropaleontological dating of the collision between the North American Plate and the Greater Antilles Arc in western Cuba. Palaios, 12(2), 133-150.

Braszus, B., Goes, S., Allen, R., Rietbrock, A., Collier, J., Harmon, N., ... \& Wilson, M. (2021). Subduction history of the Caribbean from upper-mantle seismic imaging and plate reconstruction. Nature communications, 12(1), 1-14. doi: $10.1038 / \mathrm{s} 41467-021-24413-0$

Bruña, J. G., Ten Brink, U. S., Carbó-Gorosabel, A., Muñoz-Martín, A., \& Ballesteros, M. G. (2009). Morphotectonics of the central Muertos thrust belt and Muertos Trough (northeastern Caribbean). Marine geology, 263(1-4), 7-33. 
Bruña, J. G., Carbó-Gorosabel, A., Estrada, P. L., Muñoz-Martín, A., Ten Brink, U. S., Ballesteros, M. G., ... \& Pazos, A. (2014). Morphostructure at the junction between the Beata ridge and the Greater Antilles island arc (offshore Hispaniola southern slope). Tectonophysics, 618, 138-163.

Buiter, S. J., Govers, R., \& Wortel, M. J. R. (2001). A modelling study of vertical surface displacements at convergent plate margins. Geophysical Journal International, 147(2), 415-427.

Burke, K., Fox, P.J. \& Sengor, A.M.C. (1978). Buoyant ocean floor and the evolution of the Caribbean. Journal of Geophysical Research, 83, 3949-3954.

Byrne, D. B., Suarez, G., \& McCann, W. R. (1985). Muertos Trough subduction-Microplate tectonics in the northern Caribbean?. Nature, 317(6036), 420-421.

Calais, E., Mazabraud, Y., Mercier de Lépinay, B., Mann, P., Mattioli, G., \& Jansma, P. (2002). Strain partitioning and fault slip rates in the northeastern Caribbean from GPS measurements. Geophysical Research Letters, 29(18), 3-1.

Cerpa, N. G., Hassani, R., Gerbault, M., \& Prévost, J. H. (2014). A fictitious domain method for lithosphere-asthenosphere interaction: Application to periodic slab folding in the upper mantle. Geochemistry, Geophysics, Geosystems, 15(5), 18521877.

Cerpa, N. G., Araya, R., Gerbault, M., \& Hassani, R. (2015). Relationship between slab dip and topography segmentation in an oblique subduction zone: Insights from numerical modeling. Geophysical Research Letters, 42(14), 5786-5795. https://doi.org/10.1002/2015GL064047

Cerpa, N. G., Guillaume, B., \& Martinod, J. (2018). The interplay between overriding plate kinematics, slab dip and tectonics. Geophysical Journal International, 215(3), 1789-1802.

Cerpa, N. G., \& Arcay, D. (2020). Overriding Plate Velocity Control on Surface Topography in 2-D Models of Subduction Zones. Geochemistry, Geophysics, Geosystems, 21(4), e2019GC008900.

Chemenda, A., Lallemand, S., \& Bokun, A. (2000). Strain partitioning and interplate friction in oblique subduction zones: Constraints provided by experimental modeling. Journal of Geophysical Research: Solid Earth, 105(B3), 5567-5581.

Chen, Z., Schellart, W. P., Strak, V., \& Duarte, J. C. (2016). Does subduction-induced mantle flow drive backarc extension?. Earth and Planetary Science Letters, 441, 200-210.

Christeson, G. L., Mann, P., Escalona, A., \& Aitken, T. J. (2008). Crustal structure of the Caribbean-northeastern South America arc-continent collision zone. Journal of Geophysical Research: Solid Earth, 113(B8).

Clark, S. A., M. Sobiesiak, C. A. Zelt, M. B. Magnani, M. S. Miller, M. J. Bezada, and A. Levander (2008), Identification and tectonic implications of a tear in the South American plate at the southern end of the Lesser Antilles, Geochem. Geophys. Geosyst., 9, Q11004, doi:10.1029/2008GC002084

Corbeau, J., Rolandone, F., Leroy, S., Guerrier, K., Keir, D., Stuart, G., ... \& Momplaisir, R. B. A. (2017). Crustal structure of western Hispaniola (Haiti) from a teleseismic receiver function study. Tectonophysics, 709, 9-19.

Cornée, J.J., Münch, P., Philippon, M., BouDagher-Fadel, M., Quillévéré, F., Melinte-Dobrinescu, M., Lebrun, J.F., Gay, A., Meyer, S., Montheil, L. and Lallemand, S., (2021). Lost islands in the northern Lesser Antilles: possible milestones in the Cenozoic dispersal of terrestrial organisms between South-America and the Greater Antilles. Earth-Science Reviews. https://doi.org/10.1016/j.earscirev.2021.103617Get

Crameri, F., \& Tackley, P. J. (2015). Parameters controlling dynamically self-consistent plate tectonics and single-sided subduction in global models of mantle convection. Journal of Geophysical Research: Solid Earth, 120(5), 3680-3706.

Cruz-Orosa, I., Sàbat, F., Ramos, E., \& Vázquez-Taset, Y. M. (2012). Synorogenic basins of central Cuba and collision between the Caribbean and North American plates. International Geology Review, 54(8), 876-906. 
Duarte, J. C., Schellart, W. P., \& Cruden, A. R. (2015). How weak is the subduction zone interface?. Geophysical Research Letters, 42(8), 2664-2673.

Escalona, A., \& Mann, P. (2011). Tectonics, basin subsidence mechanisms, and paleogeography of the Caribbean-South American plate boundary zone. Marine and Petroleum Geology, 28(1), 8-39.

Faccenna, C., Oncken, O., Holt, A. F., \& Becker, T. W. (2017). Initiation of the Andean orogeny by lower mantle subduction. Earth and Planetary Science Letters, 463, 189-201.

Feuillet, N., Manighetti, I., Tapponnier, P., \& Jacques, E. (2002). Arc parallel extension and localization of volcanic complexes in Guadeloupe, Lesser Antilles. Journal of Geophysical Research: Solid Earth, 107(B12), ETG-3

Forsyth, D., \& Uyeda, S. (1975). On the relative importance of the driving forces of plate motion. Geophysical Journal International, 43(1), 163-200.

Fox, P. J., Schreiber, E., \& Heezen, B. C. (1971). The geology of the Caribbean crust: Tertiary sediments, granitic and basic rocks from the Aves ridge. Tectonophysics, 12(2), 89-109.

Funiciello, F., Faccenna, C., Giardini, D., \& Regenauer-Lieb, K. (2003). Dynamics of retreating slabs: 2. Insights from threedimensional laboratory experiments. Journal of Geophysical Research: Solid Earth, 108(B4).

Garcia-Casco, A., Iturralde-Vinent, M. A., \& Pindell, J. (2008). latest Cretaceous collision/accretion between the Caribbean Plate and Caribeana: origin of metamorphic terranes in the Greater Antilles. International Geology Review, 50(9), 781809.

Garel, F., Goes, S., Davies, D. R., Davies, J. H., Kramer, S. C., \& Wilson, C. R. (2014). Interaction of subducted slabs with the mantle transition-zone: A regime diagram from 2-D thermo-mechanical models with a mobile trench and an overriding plate. Geochemistry, Geophysics, Geosystems, 15(5), 1739-1765

Garrocq, C., Lallemand, S., Marcaillou, B., Lebrun, J. F., Padron, C., Klingelhoefer, F., ... \& GARANTI cruise team (2021). Genetic relations between the Aves Ridge and the Grenada back-arc Basin, East Caribbean Sea. Journal of Geophysical Research: Solid Earth,

Gibert, G., Gerbault, M., Hassani, R., \& Tric, E. (2012). Dependency of slab geometry on absolute velocities and conditions for cyclicity: insights from numerical modelling. Geophysical Journal International, 189(2), 747-760.

Gordon, M. B., Mann, P., Cáceres, D., \& Flores, R. (1997). Cenozoic tectonic history of the North America-Caribbean plate boundary zone in western Cuba. Journal of Geophysical Research: Solid Earth, 102(B5), 10055-10082.

Govers, R., \& Wortel, M. J. R. (2005). Lithosphere tearing at STEP faults: Response to edges of subduction zones. Earth and Planetary Science Letters, 236(1-2), 505-523.

Grindlay, N. R., Mann, P., Dolan, J. F., \& van Gestel, J. P. (2005). Neotectonics and subsidence of the northern Puerto RicoVirgin Islands margin in response to the oblique subduction of high-standing ridges. Active Tectonics and Seismic Hazards of Puerto Rico, the Virgin Islands, and Offshore Areas, 385, 31-60.

Guillaume, B., Hertgen, S., Martinod, J., \& Cerpa, N. G. (2018). Slab dip, surface tectonics: How and when do they change following an acceleration/slow down of the overriding plate?. Tectonophysics, 726, 110-120.

Guillaume, B., Funiciello, F., \& Faccenna, C. (2021). Interplays between mantle flow and slab pull at subduction zones in 3D. Journal of Geophysical Research: Solid Earth, 126(5), e2020JB021574.

Hassani, R., Jongmans, D., \& Chéry, J. (1997). Study of plate deformation and stress in subduction processes using twodimensional numerical models. Journal of Geophysical Research: Solid Earth, 102(B8), 17951-17965. 
Heubeck, C., Mann, P., Dolan, J., \& Monechi, S. (1991). Diachronous uplift and recycling of sedimentary basins during Cenozoic tectonic transpression, northeastern Caribbean plate margin. Sedimentary geology, 70(1), 1-32.

Huerta, P. H., \& Pérez-Estaun, A. (2002). Estructura del cinturón de pliegues y cabalgamientos de Peralta, República Dominicana. Acta geológica hispánica, 37(2-3), 183-205.

Iturralde-Vinent, M. A. (1994). Cuban geology: A new plate-tectonic synthesis. Journal of Petroleum Geology, 17(1), 39-69.

Iturralde-Vinent, M., \& MacPhee, R. D. (1999). Paleogeography of the Caribbean region: implications for Cenozoic biogeography. Bulletin of the AMNH: no. 238.

James, K. H. (2009). In situ origin of the Caribbean: discussion of data. Geological Society, London, Special Publications, 328(1), 77-125.

Jolly, W. T., Schellekens, J. H., \& Dickin, A. P. (2007). High-Mg andesites and related lavas from southwest Puerto Rico (Greater Antilles Island Arc): Petrogenetic links with emplacement of the late Cretaceous Caribbean mantle plume. Lithos, 98(1-4), 1-26.

Kopp, H., Weinzierl, W., Becel, A., Charvis, P., Evain, M., Flueh, E. R., ... \& Roux, E. (2011). Deep structure of the central Lesser Antilles Island Arc: relevance for the formation of continental crust. Earth and Planetary Science Letters, 304(12), 121-134

Laó-Dávila, D. A., Llerandi-Román, P. A., \& Anderson, T. H. (2012). Cretaceous-Paleogene thrust emplacement of serpentinite in southwestern Puerto Rico. Bulletin, 124(7-8), 1169-1190.

Laó-Dávila, D. A. (2014). Collisional zones in Puerto Rico and the northern Caribbean. Journal of South American Earth Sciences, 54, 1-19.

Laurencin, M., Marcaillou, B., Graindorge, D., Klingelhoefer, F., Lallemand, S., Laigle, M., \& Lebrun, J. F. (2017). The polyphased tectonic evolution of the Anegada Passage in the northern Lesser Antilles subduction zone. Tectonics, 36(5), 945-961.

Laurencin, M., Marcaillou, B., Graindorge, D., Lebrun, J. F., Klingelhoefer, F., Boucard, M., ... \& Schenini, L. (2019). The Bunce Fault and Strain Partitioning in the Northern Lesser Antilles. Geophysical Research Letters, 46(16), 9573-9582.

Lallemand, S., Heuret, A., Faccenna, C., \& Funiciello, F. (2008). Subduction dynamics as revealed by trench migration. Tectonics, 27(3).

Lee, C., \& King, S. D. (2011). Dynamic buckling of subducting slabs reconciles geological and geophysical observations. Earth and Planetary Science Letters, 312(3-4), 360-370

Legendre, L., Philippon, M., Münch, P., Leticee, J. L., Noury, M., Maincent, G., ... \& Mazabraud, Y. (2018). Trench bending initiation: Upper plate strain pattern and volcanism. Insights from the Lesser Antilles arc, St. Barthelemy Island, French West Indies. Tectonics, 37(9), 2777-2797.

Leroy, S., Mauffret, A., Patriat, P., \& Mercier de Lépinay, B. (2000). An alternative interpretation of the Cayman trough evolution from a reidentification of magnetic anomalies. Geophysical Journal International, 141(3), 539-557.

Mann, P., Calais, E., Ruegg, J. C., DeMets, C., Jansma, P. E., \& Mattioli, G. S. (2002). Oblique collision in the northeastern Caribbean from GPS measurements and geological observations. Tectonics, 21(6), 7-1.

Mann, P. (2007). Overview of the tectonic history of northern Central America. Geological Society of America Special Papers, 428, 1-19. 
Marivaux, L., Vélez-Juarbe, J., Merzeraud, G., Pujos, F., Vinola Lopez, L. W., Boivin, M., ... \& Antoine, P. O. (2020). early Oligocene chinchilloid caviomorphs from Puerto Rico and the initial rodent colonization of the West Indies. Proceedings of the Royal Society B, 287(1920), 20192806.

Mauffret, A., \& Leroy, S. (1999). Neogene intraplate deformation of the Caribbean plate at the Beata Ridge. In Sedimentary basins of the world (Vol. 4, pp. 627-669). Elsevier.

Melekhova, E., Schlaphorst, D., Blundy, J., Kendall, J. M., Connolly, C., McCarthy, A., \& Arculus, R. (2019). lateral variation in crustal structure along the Lesser Antilles arc from petrology of crustal xenoliths and seismic receiver functions. Earth and Planetary Science Letters, 516, 12-24.

Meschede, M., \& Frisch, W. (1998). A plate-tectonic model for the Mesozoic and early Cenozoic history of the Caribbean plate. Tectonophysics, 296(3-4), 269-291.

Montes, C., Rodriguez-Corcho, A. F., Bayona, G., Hoyos, N., Zapata, S., \& Cardona, A. (2019). Continental margin response to multiple arc-continent collisions: The northern Andes-Caribbean margin. Earth-Science Reviews, 198, 102903.

Neill, I., Kerr, A. C., Hastie, A. R., Stanek, K.-P., \& Millar, I. L. (2011). Origin of the Aves Ridge and Dutch-Venezuelan Antilles: Interaction of the Cretaceous 'Great Arc' and Caribbean-Colombian Oceanic Plateau? Journal of the Geological Society, 168(2), 333-348.

Padron, C., Klingelhoefer, F., Marcaillou, B., Lebrun, J. F., Lallemand, S., Garrocq, C., ... \& GARANTI cruise team. (2018). Deep structure of the Grenada Basin from wide-angle seismic, bathymetric and gravity data. Journal of Geophysical Research: Solid Earth

Padron, C., E. Deville, P. Huyghe, S. Lallemant, and J. F. Lebrun, 2020, Diffuse deformation processes at the southeastern boundary of the Caribbean plate, in C. Bartolini, ed., South America-Caribbean-Central Atlantic plate boundary: Tectonic evolution, basin architecture, and petroleum systems: AAPG Memoir 123, in press

Philippon, M., Cornée, J. J., Münch, P., Van Hinsbergen, D. J., Boudagher-Fadel, M., Gailler, L., ... \& Lebrun, J. F. (2020a). Eocene intra-plate shortening responsible for the rise of a faunal pathway in the northeastern Caribbean realm. PloS one, 15(10), $\mathrm{e} 0241000$.

Philippon, M., Van Hinsbergen, D. J., Boschman, L. M., Gossink, L. A., Cornée, J. J., BouDagher-Fadel, M., ... \& Munch, P. (2020b). Caribbean intra-plate deformation: Paleomagnetic evidence from St. Barthélemy Island for post-Oligocene rotation in the Lesser Antilles forearc. Tectonophysics, 777, 228323.

Pindell, J. L., \& Barrett, S. F. (1990). Caribbean plate tectonic history. The Caribbean Region, volume H of The Geology of North America, 405-432.

Pindell, J. L., \& Kennan, L. (2009). Tectonic evolution of the Gulf of Mexico, Caribbean and northern South America in the mantle reference frame: an update. Geological Society, London, Special Publications, 328(1), 1-55.

Pubellier, M., Mauffret, A., Leroy, S., Vila, J. M., \& Amilcar, H. (2000). Plate boundary readjustment in oblique convergence: Example of the Neogene of Hispaniola, Greater Antilles. Tectonics, 19(4), 630-648.

Ramos, V. A. (2009). Anatomy and global context of the Andes: Main geologic features and the Andean orogenic cycle. Backbone of the Americas: Shallow subduction, plateau uplift, and ridge and terrane collision, 204, 31-65.

Rodríguez-Zurrunero, A., Granja-Bruña, J. L., Muñoz-Martín, A., Leroy, S., ten Brink, U., Gorosabel-Araus, J. M., ... \& Carbó-Gorosabel, A. (2020). Along-strike segmentation in the northern Caribbean plate boundary zone (Hispaniola sector): Tectonic implications. Tectonophysics, 776, 228322.

Román, Y. A., Pujols, E. J., Cavosie, A. J., \& Stockli, D. F. (2020). Timing and magnitude of progressive exhumation and deformation associated with Eocene arc-continent collision in the NE Caribbean plate. GSA Bulletin 
Rosencrantz, E., Ross, M. I., \& Sclater, J. G. (1988). Age and spreading history of the Cayman Trough as determined from depth, heat flow, and magnetic anomalies. Journal of Geophysical Research: Solid Earth, 93(B3), 2141-2157.

Rosencrantz, E. (1990). Structure and tectonics of the Yucatan Basin, Caribbean Sea, as determined from seismic reflection studies. Tectonics, 9(5), 1037-1059.

Royden, L. H., \& Holt, A. F. Subduction Dynamics and Mantle Pressure:(i) An analytical framework relating Subduction Geometry, Plate Motion, and Asthenospheric Pressure. Geochemistry, Geophysics, Geosystems, e2020GC009032.

Russo, R. M., \& Silver, P. G. (1994). Trench-parallel flow beneath the Nazca plate from seismic anisotropy. Science, 263(5150), 1105-1111.

Ryan, H. F., \& Scholl, D. W. (1989). The evolution of forearc structures along an oblique convergent margin, central Aleutian arc. Tectonics, 8(3), 497-516.

Schellart, W. P. (2004). Kinematics of subduction and subduction-induced flow in the upper mantle. Journal of Geophysical Research: Solid Earth, 109(B7).

Schellart, W. P., Freeman, J., Stegman, D. R., Moresi, L., \& May, D. (2007). Evolution and diversity of subduction zones controlled by slab width. Nature, 446(7133), 308-311.

Schellart, W. P., \& Moresi, L. (2013). A new driving mechanism for backarc extension and backarc shortening through slab sinking induced toroidal and poloidal mantle flow: Results from dynamic subduction models with an overriding plate. Journal of Geophysical Research: Solid Earth, 118(6), 3221-3248.

Schellekens, J. H. (1991). Late Jurassic to Eocene geochemical evolution of volcanic rocks in Puerto Rico. Geophysical Research Letters, 18(3), 553-556.

Sigloch, K., \& Mihalynuk, M. G. (2013). Intra-oceanic subduction shaped the assembly of Cordilleran North America. Nature, 496(7443), 50-56.

Speed, R. C. (1989). Tectonic evolution of St. Croix: implications for tectonics of the northeastern Caribbean. Terrestrial and marine Geology of St. Croix, US Virgin Islands, Spec Publ, (8), 9-36.

Stanek, K. P., Maresch, W. V., \& Pindell, J. L. (2009). The geotectonic story of the northwestern branch of the Caribbean Arc: implications from structural and geochronological data of Cuba. Geological Society, London, Special Publications, 328(1), 361-398.

ten Brink, U., \& Lin, J. (2004). Stress interaction between subduction earthquakes and forearc strike-slip faults: Modeling and application to the northern Caribbean plate boundary. Journal of Geophysical Research: Solid Earth, 109(B12).

ten Brink, U., Stephen Marshak, José-Luis Granja Bruña; Bivergent thrust wedges surrounding oceanic island arcs: Insight from observations and sandbox models of the northeastern Caribbean plate. GSA Bulletin 2009;; 121 (11-12): 1522-1536.

Tovish, A., Schubert, G., \& Luyendyk, B. P. (1978). Mantle flow pressure and the angle of subduction: Non-Newtonian corner flows. Journal of Geophysical Research: Solid Earth, 83(B12), 5892-5898.

VanDecar, J. C., R. M. Russo, D. E. James, W. B. Ambeh, and M. Franke, Aseismic continuation of the Lesser Antilles slab beneath continental South America, J. Geophys. Res., 108(B1), 2043, doi:10.1029/2001JB000884, 2003.

van Benthem, S., Govers, R., Spakman, W., \& Wortel, R. (2013). Tectonic evolution and mantle structure of the Caribbean. Journal of Geophysical Research: Solid Earth, 118(6), 3019-3036. https://doi.org/10.1002/jgrb.50235

van Benthem, S., Govers, R., \& Wortel, R. (2014). What drives microplate motion and deformation in the northeastern Caribbean plate boundary region?. Tectonics, 33(5), 850-873. 
Van Fossen, M. C., Channell, J. E., \& Schellekens, J. H. (1989). Paleomagnetic evidence for Tertiary anticlockwise rotation in southwest Puerto Rico. Geophysical Research Letters, 16(8), 819-822.

Wallace, L. M., McCaffrey, R., Beavan, J., \& Ellis, S. (2005). Rapid microplate rotations and backarc rifting at the transition between collision and subduction. Geology, 33(11), 857-860.

Wallace, L. M., Ellis, S., \& Mann, P. (2009). Collisional model for rapid fore-arc block rotations, arc curvature, and episodic back-arc rifting in subduction settings. Geochemistry, Geophysics, Geosystems, 10(5).

Wright, J. E., \& Wyld, S. J. (2011). late Cretaceous subduction initiation on the eastern margin of the Caribbean-Colombian Oceanic Plateau: One Great Arc of the Caribbean (?). Geosphere, 7(2), 468-493.

Zhu, H., Stern, R. J., \& Yang, J. (2020). Seismic evidence for subduction-induced mantle flows underneath middle America. Nature Communications, 11(1), 1-12. 